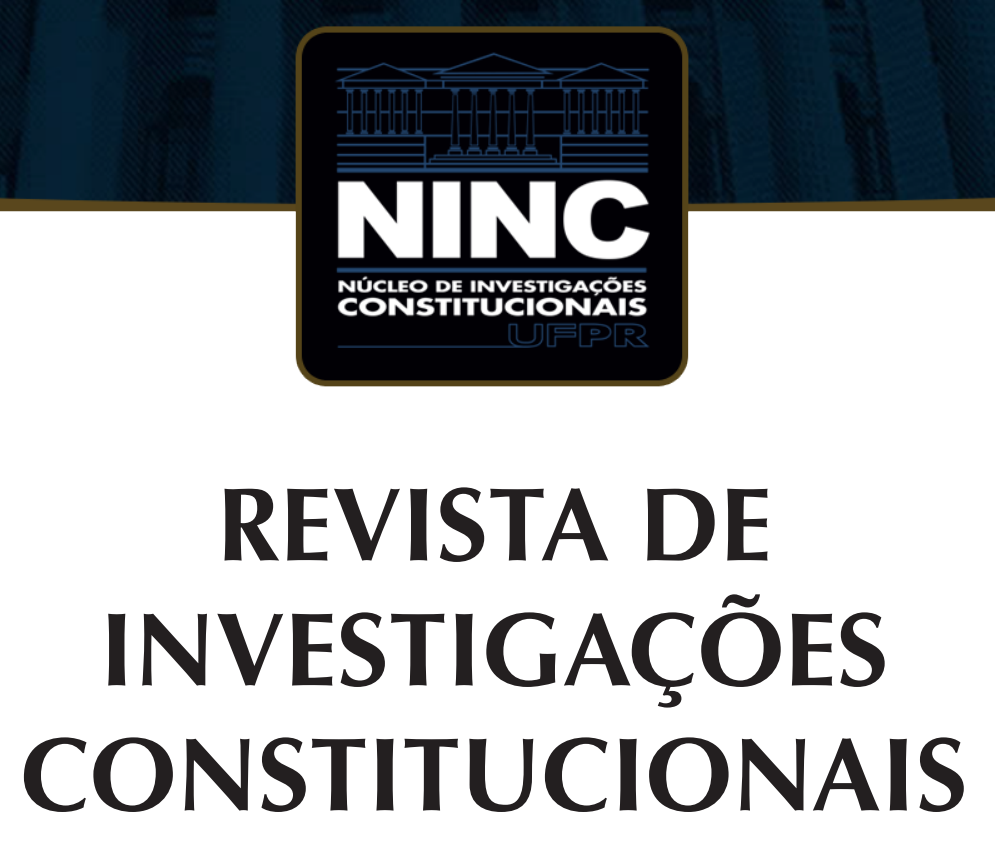

JOURNAL OF CONSTITUTIONAL RESEARCH

vol. 7 | n. 1 | janeiro/abril 2020 | ISSN 2359-5639 | Periodicidade quadrimestral Curitiba | Núcleo de Investigações Constitucionais da UFPR | www.ninc.com.br 


\title{
Materializando diálogos institucionais na judicialização da saúde pública - propostas de convenções processuais coletivas, LINDB e transparência
}

\section{Materializing institutional dialogues on universal health care litigation - proposals of contracts of procedure, LINDB and transparency}

\author{
CAIO GAMA MASCARENHAS ${ }^{1, *}$ \\ ' Universidade Federal do Mato Grosso do Sul (Campo Grande, Mato Grosso do Sul, Brasil) \\ caiogm_jus@live.com \\ http://orcid.org/0000-0003-2435-4949
}

\section{LÍDIA MARIA RIBAS ${ }^{1, * *}$}

' Universidade Federal do Mato Grosso do Sul (Campo Grande, Mato Grosso do Sul, Brasil) limaribas@uol.com.br

https://orcid.org/0000-0003-4764-6661

Recebido/Received: 26.05 .2019 / May $26^{\text {th }}, 2019$ Aprovado/Approved: 24.06 .2020 / June $24^{\text {th }}, 2020$

Resumo

Propõe-se trazer uma perspectiva da judicialização da saúde sob a ótica dos diálogos institucionais e da flexibilidade procedimental, buscando soluções para o problema de forma conjunta entre os poderes de Estado. É fundamental que se busquem métodos de indução de
Abstract

The purpose of this paper is bringing the problem of universal health care (SUS) litigation to the perspective of institutional dialogues and procedural flexibility, seeking solutions for the issue jointly between the State Powers. It is fundamental to seek methods of induction of greater

Como citar esse artigo/How to cite this article: MASCARENHAS, Caio Gama; RIBAS, Lídia Maria. Materializando diálogos institucionais na judicialização da saúde pública - propostas de convenções processuais coletivas, LINDB e transparência. Revista de Investigações Constitucionais, Curitiba, vol. 7, n. 1, p. 285-317, jan./abr. 2020. DOI: 10.5380/rinc.v7i1.67088.

* Mestrado em Direito em andamento pela Universidade Federal de Mato Grosso do Sul (Campo Grande-MS, Brasil). Graduado pela Pontifícia Universidade Católica de Goiás PUC-GO (2009) e especializado em Direito Constitucional e Administrativo pela mesma instituição (2013). Integrante do grupo de pesquisa "Direito, Políticas Públicas e Desenvolvimento Sustentável". Partici-

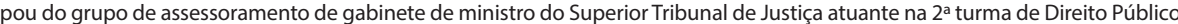
(2014-2015). Procurador do Estado do Mato Grosso do Sul (2015- presente). E-mail: caiogm_jus@live.com

** Pesquisadora e professora permanente do Mestrado em Direitos Humanos da Universidade Federal do Mato Grosso do Sul (Campo Grande-MS, Brasil). Doutora e Mestre em Direito do Estado pela Pontifícia Universidade Católica de São Paulo (São Paulo-SP, Brasil). Realizou Pós-doutorado na Faculdade de Direito da Universidade de Coimbra em Direito Público; na Faculdade de Direito da Universidade Nova de Lisboa e em Ciências Jurídicas e Sociais, na Universidade do Museo Social da Argentina UMSA/IEAT - Instituto Educacional Almirante Tamandaré. Advogada e Economista, com graduação em Formação de Professores e em Administração de Empresas pela Universidade Católica Dom Bosco. E-mail: limaribas@uol.com.br. 
maior responsabilidade e economicidade por parte dos poderes. Destarte, inquire-se: quais são os problemas práticos da judicialização nas áreas da saúde e da gestão pública orçamentária? É possível que convenções processuais regulamentem decisões que afetem a gestão pública orçamentária? Como fornecer accountability nos acordos entre o Judiciário e o Executivo no âmbito do Sistema Único de Saúde? Algumas outras teorias são utilizadas: como a das capacidades dos poderes e do Processo Civil do Estado Constitucional. Faz-se ainda uma interpretação conjunta entre o artigo 190 do CPC/2015 e os artigos 20, 22 e 26 da Lei de Introdução de Normas de Direito Brasileiro. Utiliza-se o método dedutivo/indutivo, por meio da pesquisa bibliográfica e documental.

Palavras-chave: negócios jurídicos processuais; políticas públicas; Sistema Único de Saúde; transparência; mecanismos alternativos de soluções de conflito. responsibility and economy efficiency from the institutions. In this sense, it is questioned: what are the main issues of universal health care litigation? Can contracts of procedure regulate decisions that affect public budget management? How to provide accountability between agreements of the Judiciary and the Executive Branch within the SUS? Some theories are used: institutional dialogues theory; theory of the institutional capabilities; theory of the Civil Process of the Constitutional State; and theory of procedural flexibility. At the normative level, a joint interpretation is made between articles 190 of CPC/2015 and 20 and 22 of LINDB. The deductive / inductive method is used, through bibliographical and documentary research.

Keywords: contracts of procedure; public policies; Brazilian Unified Health System; transparency; alternative methods of conflicts solution.

\section{SUMÁRIO}

1. Introdução; 2. A judicialização da saúde e o imperativo diálogo equilibrado entre instituições; 2.1. (In)capacidades institucionais diante de problemas processuaise sanitários dajudicialização da saúde; 2.2. (In)capacidades institucionais diante de problemas de gestão financeira-orçamentária na judicialização da saúde; 2.3. O necessário diálogo equilibrado entre as instituições; 3. Convenção processual, LINDB e os parâmetros para decisões judiciais conforme normas de gestão pública; 3.1. Os acordos processuais coletivos ou protocolos institucionais; 3.2. Uma proposta: acordos processuais coletivos ou protocolos institucionais na seara da gestão pública orçamentária; 3.3. Transparência e accountability de verbas públicas utilizadas nas demandas judiciais contra o SUS; 4 . Considerações finais;

5. Referências.

\section{INTRODUÇÃO}

Harmonizar a judicialização dos direitos sociais e econômicos com a complexa atividade da gestão pública é uma das maiores dificuldades dos poderes da república atualmente. A Administração Pública precisa encontrar a melhor forma de direcionar, de maneira eficiente e efetiva, as receitas tributárias para os sistemas públicos de saúde e educação. Uma política pública social pode ser justa, mas ineficiente em determinados setores (a exemplo da universalidade de atendimento e integralidade de tratamentos no SUS). Por outro lado, uma política pode ser economicamente eficiente, mas injusta socialmente (a exemplo de tributos que não atendem ao princípio da capacidade contributiva). No entanto, a escolha de como arrecadar, onde se alocar recursos e como se alocar sempre foi uma decisão política, havendo seus erros e acertos próprios da atividade do gestor público.

O terreno da escolha política é marcado pela escassez de recursos, não havendo como fornecer todas as pretensões materiais requeridas pela população de forma 
irrestrita. A judicialização do direito de assistência à saúde, cuja satisfação exige do Estado prestações de cunho material e custo de recursos públicos, é um tema bastante delicado do ponto de vista democrático.

Tal discussão acaba por adentrar na teoria dos diálogos institucionais e qual seria a melhor forma de lidar com os problemas da judicialização da saúde por todos os poderes. $\mathrm{O}$ trabalho, embora tenha embasamento teórico e principiológico, possui como escopo principal uma visão pragmática e prática dos problemas e desafios da gestão da saúde e da judicialização. Evita-se qualquer defesa de valores abstratos e interpretações que inviabilizem todas as soluções alternativas que visem uma mitigação dos problemas.

A proposta do artigo é trazer uma perspectiva da judicialização da saúde sob a ótica dos diálogos institucionais e da flexibilidade procedimental, buscando uma solução do problema de forma conjunta entre os poderes de Estado por meio de convenções processuais. É fundamental que se busquem métodos de indução de maior responsabilidade técnica e economicidade por parte dos poderes nos serviços públicos fornecidos pelo SUS. Três são os problemas de pesquisa apresentados: quais são os problemas práticos da judicialização nas áreas da saúde e da gestão pública orçamentária? É possível que convenções processuais regulamentem decisões que afetem a gestão pública orçamentária? Como fornecer accountability nos acordos entre o Poder Judiciário e o Poder Executivo no âmbito do SUS?

Algumas teorias são utilizadas: teoria dos diálogos institucionais; teoria das capacidades dos poderes; teoria do Processo Civil do Estado Constitucional; teoria do orçamento republicano e liberdade igual. No plano normativo, analisam-se os artigos 190 do CPC/2015 e 20, 22 e 26 da Lei de Introdução de Normas de Direito Brasileiro (LINDB).

As fontes de dados referentes aos impactos são secundárias: livros, teses de doutorado, dissertações, artigos e informações obtidas por meio do Departamento de Informática do SUS (DATASUS). O trabalho é desenvolvido a partir dos métodos indutivo e dedutivo, utilizando-se de material bibliográfico e documental. Por se tratar de um estudo descritivo e exploratório, é realizado com base na pesquisa bibliográfica e documental, utilizando-se por vezes do método dedutivo e, outras vezes, do indutivo, principalmente nas críticas e reflexões acerca da doutrina, estudos e textos normativos.

\section{JUDICIALIZAÇÃO DA SAÚDE E O IMPERATIVO DIÁLOGO EQUI- LIBRADO ENTRE INSTITUIÇÕES}

Equidade e eficiência são tradicionalmente vistas como metas concorrentes na elaboração de políticas públicas. Pode-se ser justo na elaboração de uma política pública, mas muitas vezes o que é justo não é economicamente eficiente. Por outro lado, o que é eficiente pode não ser justo. Tais fatos não impedem, no entanto, que certas 
políticas sejam justas e economicamente eficientes - promovendo equidade e desenvolvimento econômico' ${ }^{1}$. Esses parâmetros, aliados às escolhas orçamentárias e à busca pela melhor técnica de gestão, são problemas próprios da Administração Pública.

O problema da judicialização da saúde diz respeito ao regime constitucional do direito fundamental à vida digna e à saúde. No ordenamento constitucional brasileiro, a saúde é direito fundamental tanto formal quanto material, gozando de regime jurídico privilegiado². Saúde talvez seja o direito fundamental mais complexo no ordenamento jurídico. Isso em razão da considerável zona de convergência com outros direitos fundamentais e bens jurídicos tutelados pela Constituição Federal³.

\section{1. (In)capacidades institucionais diante de problemas processuais e sanitários da judicialização da saúde}

A Constituição Federal de 1988 determinou a proteção de um vasto rol de direitos individuais e sociais. Provocou-se o chamado "choque de direitos", trazendo, em um só momento, um conjunto de prestações sociais subjetivas que deveriam ser garantidas pelo Estado. O poder público, no entanto, possuía (e ainda possui) uma realidade fática bem diversa da realidade constitucional, não dispondo de estrutura nem capacidade para lidar com a deficiência de proporção tão alta como os direitos sociais constitucionalmente garantidos existentes ${ }^{4}$.

Ao lado da efetividade dos direitos, existe a questão das escolhas trágicas que os políticos devem fazer com certa frequência. Guido Calabresi e Philip Bobbitt, debruçando-se sobre questões referentes às escolhas políticas na alocação de recursos, explicam que, embora a escassez possa muitas vezes ser evitada para alguns bens, tornando-os disponíveis sem custo para todos, ela não pode ser evitada para todos os bens ${ }^{5}$.

Há ainda o problema das capacidades técnicas de cada instituição. Neil Komesar, analisando as capacidades técnicas das instituições, pondera sobre o Poder Judiciário substituir decisões do Poder Legislativo. Conforme o autor, os poderes da república diferem em suas capacidades para resolver questões substantivas, e o grau e o tipo dessas diferenças podem variar significativamente. A dificuldade relativa de várias questões substantivas de políticas públicas surge de realidades sociais e políticas muito variadas e sutis. Tais questões possuem uma complexidade muito grande para serem

\footnotetext{
HECKMAN, James J. The economics of inequality: The value of early childhood education. American Educator, v. 35, n. 1, 2011, p. 31.

2 SARLET, Ingo Wolfgang. Comentário ao artigo 196. In: CANOTILHO, J. J. Gomes; MENDES, Gilmar F.; SARLET, Ingo W. Comentários à Constituição do Brasil. São Paulo: Saraiva/Almedina, 2013, p. 3550.

Ibid., p. 3550.

4 ZEBULUM, José Carlos. Juizados Especiais: uma solução para a questão da saúde? Cadernos Ibero-Americanos de Direito Sanitário, v. 6, n 1, p. 189.

5 CALABRESI, Guido; BOBBITT, Philip. Tragic choices. W.W. Norton \& company. Nova lorque. 1984, p. 18.
} 
adequadamente capturadas nas amplas categorias analíticas de princípio fundamental, discricionariedade política, economia ou processo democrático ${ }^{6}$.

Na área da saúde pública, o Poder Judiciário possui clara deficiência técnica para lidar com questões referentes ao SUS, seja em razão da complexidade própria da área da saúde, seja em razão da ausência de conhecimentos na área de gestão pública ${ }^{7}$. Talvez um exemplo que evidencie de forma clara a falta de capacidade técnica do Poder judiciário para lidar com as questões da área da saúde seja a concessão, por meio de milhares de liminares, da substância fosfoetanolamina a determinados pacientes com câncer ${ }^{8}$.

A ausência de capacidade técnica do Poder Judiciário para lidar com a complexidade da saúde ainda faz com que outros agentes com interesse econômico entrem no cenário. Vários são os aspectos necessários para a compreensão da enorme complexidade da área da saúde, que vão muito além do paciente (titular do direito à saúde) e passam a envolver outros personagens: a classe médica como detentora do conhecimento da ciência e dos protocolos clínicos validados para avaliação de doenças e prescrição de tratamentos; os interesses no mercado da saúde, considerando especialmente os laboratórios farmacêuticos, além de ONGs; e os escritórios de advocacia interessados na judicialização?.

A judicialização da saúde implica, de fato, a atuação do médico, que prescreve determinado tratamento ou medicamento que vem a ser pleiteado pela via judicial. Em que pese a relevância da opção pelo tratamento indicado, a questão vai muito além da decisão do médico porque implica o custo referente aos tratamentos e medicamentos prescritos. Tais tratamentos e medicamentos devem ser financiados por alguém (no caso, pelo Estado) e proporcionam elevados lucros neste mercado. Como em todo

6 KOMESAR, Neil K. Taking Institutions Seriously: Introduction to a Strategy for Constitutional Analysis. U. Chi. L. Rev., v. 51, p. 367-368.

7 Na área da saúde, destaca-se que "[...] raciocínios estritamente jurídicos e o mundo do Direito possuem suas limitações e somente uma aproximação interinstitucional é capaz de responder satisfatoriamente às dificuldades nesta área" (AVILA, Ana Paula Oliveira; DE MELO, Karen Cristina Correa. Separação de poderes e diálogos institucionais nos litígios envolvendo o direito à saúde. Revista de Investigações Constitucionais, v. $5, n^{\circ} 1$, p. 87).

8 "Nesta era da velocidade e informação, disseminou-se a promessa de que a droga representava a descoberta da cura do câncer. Como decorrência, sem o aval de quaisquer autoridades da oncologia ou do Instituto Nacional do Câncer (INCA) que atestassem níveis mínimos de segurança na utilização desta substância, o Poder Judiciário vinha concedendo as liminares que exigiam o fornecimento da fosfoetanolamina até que o STF suspendesse a eficácia da lei" (AVILA, Ana Paula Oliveira; DE MELO, Karen Cristina Correa. Separação de poderes e diálogos institucionais nos litígios envolvendo o direito à saúde. Revista de Investigações Constitucionais, v. 5 , n० 1, p. 87).

9 AVILA, Ana Paula Oliveira; DE MELO, Karen Cristina Correa. Separação de poderes e diálogos institucionais nos litígios envolvendo o direito à saúde. Revista de Investigações Constitucionais, v. 5, n 1, p. 88. 
mercado lucrativo, diversos interesses atuantes e, por vezes, conflitantes podem ser identificados ${ }^{10}$.

Um fator que passa a ser analisado na área da saúde é a presença do Poder Econômico ${ }^{11}$ das grandes corporações privadas. Em determinado ponto, passa a haver um conflito de interesses entre a saúde pública e o lucro de determinados setores da iniciativa privada ${ }^{12}$. Há grande interesse econômico do mercado farmacêutico nas ações em saúde julgadas pelo Poder Judiciário. Por outro lado, se não há interesse econômico, alguns tratamentos médicos acabam prejudicados ${ }^{13}$.

Com o intuito de dar maior uniformidade e segurança jurídica no fornecimento de medicamentos e tratamentos pelo Poder Público, o Superior Tribunal de Justiça (STJ) fixou, no REsp 1657156/RJ (precedente vinculante), alguns parâmetros a serem seguidos pelo Poder Judiciário nas demandas da saúde. A tese fixada pelo Tribunal Superior foi a seguinte ${ }^{14}$ :

A concessão dos medicamentos não incorporados em atos normativos do SUS exige a presença cumulativa dos seguintes requisitos: I) Comprovação, por meio de laudo médico fundamentado e circunstanciado expedido por médico que assiste o paciente, da imprescindibilidade ou necessidade do medicamento, assim como da ineficácia, para o tratamento da moléstia, dos fármacos fornecidos pelo SUS; II) incapacidade financeira de arcar com o custo do medicamento prescrito; III) existência de registro do medicamento na ANVISA, observados os usos autorizados pela agência.

10 AVILA, Ana Paula Oliveira; DE MELO, Karen Cristina Correa. Separação de poderes e diálogos institucionais nos litígios envolvendo o direito à saúde. Revista de Investigações Constitucionais, v. 5, nº 1, p. 88.

11 Sobre o conceito de Poder econômico:"Pode-se dizer, destarte, que o poder econômico se apresenta como a capacidade de impor uma conduta, submetendo ao modelo de apropriação os resultados da produção, da distribuição e do consumo na sociedade. A finalidade é a obtenção do lucro de bens e serviços mediante a atividade econômica" (ROCASOLANO, Maria Mendez; SILVEIRA, Vladmir Oliveira da. Direitos Humanos: conceitos, significados e funções. São Paulo: Saraiva, 2010, p. 52).

12 Reportagem da Época informa que há casos em que os médicos que indicam os tratamentos não fornecidos pelo SUS já fazem os encaminhamentos para determinados escritórios de advocacia especializados no assunto, como o caso do medicamento Soliris (eculizumab), que possui um custo individual de mais de 800 mil por ano. As fabricantes de medicamentos inclusive fornecem patrocínios a tais médicos a darem aulas e palestras sobre doenças e os tratamentos onerosos. São comuns as ONGs financiadas por empresas farmacêuticas que se associam com escritórios de advocacia. Disse o secretário da saúde do Estado de São Paulo em 2012, Giovanni Guido Cerri: "Isso virou uma grande indústria. Alguns médicos recebem estímulos do fabricante (viagens, benefícios) para prescrever medicamentos de alto custo. As empresas financiam as ONGs de pacientes e a isso tudo se associam os advogados". Disponível em: <http://revistaepoca.globo.com/tempo/ noticia/2012/03/o-paciente-de-r-800-mil.html>. Acesso em: 27 mar. 2019.

13 Houve aumento, nos últimos anos, do número de sífilis congênita em decorrência do desabastecimento da medicação Penicilina Benzatina em todos os estados brasileiros. Um dos principais motivos para a dificuldade no fornecimento e disponibilização na rede pública deve-se ao fato de ser considerada uma droga muito barata, proporcionando baixo lucro aos fabricantes (AVILA, Ana Paula Oliveira; DE MELO, Karen Cristina Correa. Separação de poderes e diálogos institucionais nos litígios envolvendo o direito à saúde, op. cit., 90).

14 BRASIL. Superior Tribunal de Justiça. REsp 1657156/RJ, Relator: Ministro Benedito Gonçalves, Primeira Seção, julgado em 25/04/2018. 
Ressalta-se que mesmo a decisão do REsp 1657156/RJ, precedente de eficácia vinculante (art. 927, III, do CPC/2015), possui sérias dificuldades práticas em sua coercibilidade nos casos de desrespeito ao julgado. ${ }^{15}$ Explicam-se os óbices: a) Perda do objeto da ação, visto que o tratamento indevido objeto da liminar é feito bem antes de a ação chegar às Cortes Superiores, podendo o paciente inclusive terminar o tratamento, mudar de medicamento ou falecer antes do julgamento do mérito da ação pela Corte Superior (o mesmo raciocínio pode ser utilizado nos casos de negativa indevida de fornecimento do medicamento). O erário dificilmente irá reaver o dinheiro indevidamente bloqueado também; b) A reclamação contra decisão que desrespeita o precedente vinculante somente é admitida quando esgotadas as instâncias ordinárias (art. 988, §5, II, do CPC/2015) e somente para garantir a autoridade da decisão proferida pelo STJ, em um caso concreto ${ }^{16}$; e c) No caso da interposição de recurso especial, se o acórdão do Tribunal de $2^{\mathrm{a}}$ instância prequestionar todos os requisitos do precedente, afastando a súmula 211 do STJ (o que é complicado na prática), a maioria dos parâmetros fixados cuidam de discussão de fatos e provas, o que é vedado rediscutir em sede de recurso especial em razão da súmula 7 do STJ17. Tal precedente também possui ainda menos coercitividade prática sobre ações de medicamentos que tramitam pelo rito dos juizados especiais, pois não há espaço para recurso especial nesse procedimento ${ }^{18}$ nem para outros recursos judiciais necessários para a tutela do direito à saúde ${ }^{19}$. O precedente

\footnotetext{
15 Uma pesquisa da Associação dos Magistrados Brasileiros (AMB), divulgada em 11/2/2019, revelou que 52\% dos juízes de primeiro grau entendem que não devem se pautar por jurisprudência, por acreditarem que o sistema de precedentes prejudica sua independência profissional. Disponível em: $<$ https://www.conjur.com. br/2019-fev-11/juizes-entendem-nao-seguir-jurisprudencia-pesquisa>. Acesso em: 04 maio 2019.

16 Sobre o que seria esgotamento de instância, cita-se um trecho de julgado da primeira seção do STJ:"[..]conforme precedente desta Corte Superior, o cabimento da reclamação prevista no art. 988, IV, do CPC/2015, exige o esgotamento de instância, de acordo com o $\S 5^{\circ}$, II, do mesmo artigo. VI - Havia, portanto, que aguardar o juízo de admissibilidade do recurso especial para, diante da eventual negativa de seguimento, exaurir a instância, nesse caso, com a interposição do agravo interno contra a decisão denegatória, nos termos do art. 1.030, I, b, e $\S 2^{\circ}$, do CPC/2015. [...]. VII - Fundada no art. 988, II, do Código de Processo Civil de 2015, a reclamação não se destina a dirimir divergência jurisprudencial entre o acórdão reclamado e precedentes do STJ. Sua função é garantir a autoridade da decisão proferida pelo STJ, em um caso concreto, que tenha sido desrespeitada na instância de origem, em processo que envolva as mesmas partes, que não é o caso dos autos. [...]". (Aglnt na Rcl 36.535/PE, Rel. Ministro Francisco Falcão, primeira seção, julgado em 13/03/2019, DJe 22/03/2019).

17 Nesse sentido: "O Tribunal de origem, com base no substrato fático-probatório - mormente em avaliação médica -, asseverou restar comprovada a necessidade da paciente quanto ao fármaco pleiteado, bem como sua vulnerabilidade financeira. A inversão do julgado, na forma pretendida, demandaria a incursão no acervo fático-probatório da causa, o que encontra óbice na Súmula 7 do STJ, segundo a qual a pretensão de simples reexame de prova não enseja Recurso Especial. [...]." (AgInt no REsp 1588095/PI, Rel. Ministro Napoleão Nunes Maia Filho, primeira turma, julgado em 13/12/2018, DJe 04/02/2019).

18 Súmula 203-STJ: “Não cabe recurso especial contra decisão proferida por órgão de segundo grau dos Juizados Especiais".

19 MASCARENHAS, Caio Gama. Recorribilidade de imediato das decisões interlocutórias nos Juizados Especiais da Fazenda Pública: isonomia e interesse público. Revista dos Juizados Especiais, v. 19, p. 23-37, 2017, p. 33-34.
} 
"vinculante", em verdade, possui mera eficácia persuasiva, submetendo-se às infinitas subjetividades cognitivas e emocionais de cada um dos milhares de magistrados do país.

Além das limitações práticas processuais, esse precedente vinculante não alcança os procedimentos cirúrgicos, também frequentemente judicializados. Os problemas da judicialização da saúde não atingem somente medicamentos, mas igualmente procedimentos cirúrgicos. Em 2015, uma investigação expôs grande esquema criminoso conhecido como "Máfia das Próteses". Em tal esquema, verificou-se o conluio entre médicos traumato-ortopedistas e empresas fornecedoras de material protético de alto custo, em que utilizavam de decisões judiciais contra o Estado para o recebimento de valores em cirurgias e procedimentos superfaturados - por meio de material de custo elevado e de qualidade e indicação duvidosas. No caso, havia várias vítimas: aqueles que se submetiam aos riscos de um procedimento cirúrgico desnecessário ou de eficácia duvidosa e os demais usuários do SUS, cujos serviços prestados em outras áreas eram afetados pelos bloqueios judiciais de verbas públicas ${ }^{20}$.

Para se ter uma ideia, no Mato Grosso do Sul, há um problema de enormes filas de espera para cirurgias ortopédicas, sendo comum que pacientes se utilizem da judicialização para realizar a cirurgia ${ }^{21}$. Conforme dados fornecidos pela Secretaria de Estado de Saúde, no entanto, de 2015 a 2018 foram efetuadas 47.288 cirurgias ortopédicas no Estado ${ }^{22}$. Não se cuida propriamente, portanto, de omissão estatal.

Na prática, os problemas de gestão orçamentária causados pela judicialização da saúde advêm principalmente da incompatibilidade prática entre a universalidade de atendimento do SUS e integralidade de fornecimento de bens e serviços. Considerando o erário como uma fonte finita de recursos, não é sustentável financeiramente ofertar todo e qualquer tratamento, independentemente de custos, a todos os usuários do SUS.

\footnotetext{
20 AVILA, Ana Paula Oliveira; DE MELO, Karen Cristina Correa. Separação de poderes e diálogos institucionais nos litígios envolvendo o direito à saúde, op. cit., 92.

21 Reportagem de título "Ação na Justiça tenta acabar com espera por cirurgias ortopédicas" destaca ação civil pública ajuizada em Dourados/MS. O objetivo da ação é conseguir atendimento para todos os pacientes na fila do sistema de regulação há mais de três meses. No pedido de liminar, os promotores e defensores pedem que esses pacientes sejam encaminhados em até 45 dias para consulta com médico ortopedista, exames e procedimentos cirúrgicos. 01/02/2018. Disponível em: <https://www.campograndenews.com.br/cidades/ interior/acao-na-justica-tenta-acabar-com-espera-por-cirurgias-ortopedicas> Acesso em: 31 de mar. 2019.

22 Informações obtidas por meio da base de dados do Departamento de Informática do SUS (DATASUS). Disponível em: <http://www2.datasus.gov.br/DATASUS/index.php?area=02 >. Acesso em: 21 abr. 2019.
} 


\section{2. (In)capacidades institucionais diante de problemas de gestão fi- nanceira-orçamentária na judicialização da saúde}

Wilson Maingué Neto defende que, havendo um conflito entre universalidade, integralidade e igualdade na distribuição de bens e serviços do SUS, não há solução plenamente satisfatória que permita compatibilizar os três princípios. $O$ autor defende que somente se pode compatibilizar, de forma satisfatória, os princípios da universalidade e igualdade. Quanto mais se aprofunda a integralidade, mais se enfraquece a universalidade e mais se esvazia a igualdade. Ofertar todo e qualquer tratamento, independentemente de preço, seria aprofundar a integralidade ${ }^{23}$.

O conflito, embora pareça evidente para o gestor público - detentor da chave do cofre e ciente das limitações do erário -, não o é para os magistrados, que geralmente não possuem essa percepção. O Poder Judiciário volta-se para a questão da efetivação dos direitos fundamentais na prática, sem entrar em detalhes sobre as especificidades dos tratamentos, custos orçamentários e técnicas de gestão pública.

Uma preocupação em relação aos bloqueios judiciais na área da saúde pública é em relação aos valores dos procedimentos e tratamentos muito acima do valor de mercado. Práticas de eficiência e economicidade são inexistentes na prática judiciária, embora sejam típicas nas aquisições administrativas de bens e serviços por parte do poder público. ${ }^{24}$

Para elaboração e execução orçamentária de políticas públicas, conforme o princípio das capacidades técnicas, o Poder Executivo possui uma enorme gama de profissionais de áreas de economia, administração, engenharia, saúde, educação, zootecnia etc. Nas atividades fins do Judiciário, entretanto, as atribuições ainda são quase que exclusivamente exercidas por pessoas com conhecimento técnico somente na área de direito. O Judiciário possui habilidades limitadas para avaliar determinada prestação social que deveria ser prestada pelo poder público e o seu respectivo custo-benefício. Nas palavras do juiz de direito André Ladeira da Rocha Leão ${ }^{25}$ :

\footnotetext{
23 Segundo o autor, a razão de ser do Sistema Único de Saúde é a universalidade - tanto que é o primeiro preceito constitucional citado textualmente no capítulo da seguridade social (universalidade da cobertura e do atendimento) e no capítulo da saúde (a saúde é direito de todos). Tal doutrina considera concebível um sistema público de saúde sem a integralidade, mas jamais sem a universalidade e igualdade (MAINGUÉ NETO, Wilson. Efetivação do Direito à Assistência à Saúde. $1^{\text {a }}$ ed. São Paulo: Max Limonad, 2016, p. 280-283).

24 Não se ignora o fato de haver crescente preocupação com essa questão, como é o caso do enunciado n 56 aprovado pela III Jornada de Direito da Saúde em 18.03.2019: "Havendo depósito judicial ou sequestro de verbas (Bacenjud) para aquisição de medicamentos, produto ou serviço, antes da apreciação do pedido, deve-se exigir da parte a apresentação prévia de até 3 (três) orçamentos, exceto nas hipóteses de complexa definição de custos (cirurgias, internações e fornecimento de insumos de uso hospitalar), em que outros parâmetros poderão ser observados".

25 LEÃO, André Ladeira da Rocha. Da universalização "judicial" do direito à saúde à uniformização de sua tutela. Coleção “CONSTITUIÇÃO DO BRASIL 30 anos 1988 - 2018”. TJMG. Belo Horizonte, 2018, p. 68.
} 
Ainda que haja espaço orçamentário para atendimento de demandas judiciais, há que se considerar se deve o Judiciário determinar esta ou aquela política pública em razão das dificuldades e limitações da atividade judicial, que não leva em conta aspectos extra-autos. O processo judicial leva em consideração os elementos trazidos para o processo e possui uma racionalidade diferente daquela necessária para a formulação de decisões mais amplas que digam respeito ao modo de implementação dos direitos no Estado Brasileiro.

Há de se ressaltar que o "espaço orçamentário" para o atendimento das demandas judiciais nas áreas de políticas públicas sociais está ficando mais restrito. Uma questão que deve entrar na equação orçamentária são as reformas constitucionais para a implementação do orçamento impositivo nos últimos anos ${ }^{26}$. Esse procedimento cuida do dever da Administração Pública de executar as programações orçamentárias, adotando os meios e as medidas necessários, com o propósito de garantir a efetiva entrega de bens e serviços à sociedade.

A programação orçamentária deixaria de ter um mero caráter autorizativo para ter um caráter impositivo, salvo em casos excepcionais que exijam a reestimativa de receita e de despesa. Logo, demandas judiciais poderão interferir diretamente em inúmeras programações orçamentarias obrigatórias. Em razão disso, também se discute a constitucionalização do dever judicial de indicar fonte de custeio para concessão de benefício ou serviço de seguridade social ${ }^{27}$.

Na perspectiva do gestor, uma dificuldade na judicialização da saúde é a ausência de previsibilidade dos impactos orçamentários das ações judiciais. Mesmo que o planejamento orçamentário seja elaborado com certo grau de flexibilidade na execução, é impossível prever com exatidão o grau de impacto de bloqueios judiciais nos fundos e na execução das políticas públicas, podendo ultrapassar a marca de um bilhão de reais após poucos anos ${ }^{28}$.

26 Esse movimento parlamentar constitucional iniciou-se com a previsão, no art. 166 da Constituição, de emendas parlamentares orçamentárias de execução obrigatória, por meio da Emenda Constitucional 86 de 2015. Em 2019, no entanto, espera-se a aprovação da "PEC do orçamento impositivo" pelas duas casas do Congresso Nacional, ampliando a abrangência da execução obrigatória das programações orçamentárias e sacramentando o orçamento impositivo na Constituição Federal.

27 A PEC da Reforma da Previdência (PEC 06/2019) estabelece uma nova redação proposta para o $\S 5^{\circ}$ do artigo 195, que, caso seja aprovada sem alterações pelo Congresso Nacional, determinará o seguinte: "Nenhum benefício ou serviço da seguridade social poderá ser criado, majorado ou estendido por ato administrativo, lei ou decisão judicial, sem a correspondente fonte de custeio total".

28 Segundo dados disponibilizados pelo Tribunal de Contas da União (TCU - Acórdão 1787/2017 - Plenário - Processo 009.253/2015-7), abrangendo união, estados e municípios, verificou-se que os gastos da União com processos judiciais referentes à saúde em 2015 foram de R\$ 1 bilhão, significando um aumento de mais de $1.300 \%$ (de R\$ 70 milhões para R\$ 1 bilhão) em sete anos. Ainda segundo os dados do TCU, o fornecimento de medicamentos, alguns sem registro no Sistema Único de Saúde, correspondia a 80\% das ações (LEITE, Ivan Corrêa; DE OLIVEIRA BASTOS, Paulo Roberto Haidamus. Judicialização da saúde: aspectos legais e impactos orçamentários. Argumentum, v. 10, n 1, 2018, p. 103). 
Em Mato Grosso do Sul, o panorama de crescimento do número de ações não se altera, tendo havido um crescimento de $79 \%$ no volume de ações de saúde em 2016 em relação a 2015, sendo observado que, quando analisado o pedido de medicamentos, o crescimento sobe para $102 \%$ no mesmo período ${ }^{29}$. Conforme divulgado pelo Tribunal de Justiça de Mato Grosso do Sul (TJMS), nos 12 meses de 2017, ano base da pesquisa do CNJ, o pagamento de pedidos judiciais de medicamentos, exames e procedimentos cirúrgicos pelo Estado totalizou R\$ 19,7 milhões. Em 2016, o valor foi de $\mathrm{R} \$ 17,4$ milhões ${ }^{30}$.

Na área da saúde, os recursos para cumprir as demandas judiciais saem do orçamento público para ações prioritárias definidas pelo gestor, como a prevenção na área de saúde básica. As demandas judiciais aumentam a iniquidade do sistema de saúde e diminuem a qualidade de vida dos que detêm menos recursos financeiros. A dignidade da pessoa humana, no âmbito do direito financeiro e orçamentário, não comporta soluções individuais, mas coletivas. Visa-se à redução das desigualdades sociais - e não a tutela de direitos de forma individualizada, buscando-se a efetivação de um orçamento republicano ${ }^{31}$.

Ao se falar em gestão financeira e orçamentária, a necessidade de equilíbrio e harmonia entre poderes é ainda mais evidente. Um conflito entre poderes pode gerar insegurança jurídica e o caos financeiro no ente estatal - ainda mais se se levar em conta a enorme multiplicidade de centros de decisão passíveis de intervir nas contas do ente público ${ }^{32}$. Não por outro motivo que a nova redação da Lei de Introdução de

29 LEITE, Ivan Corrêa; DE OLIVEIRA BASTOS, Paulo Roberto Haidamus. Judicialização da saúde: aspectos legais e impactos orçamentários. Argumentum, v. 10, n 1, 2018, p. 103.

30 Informações disponíveis em: <https://www.correiodoestado.com.br/cidades/ms-e-o-estado-com-maior-volume-de-acoes-judiciais-em-saude/349327/> Acesso em: 31 mar. 2019.

31 Segundo Fernando Facury Scaff: "O orçamento público, ao arrecadar de todos e ter por comando - pelo menos no Brasil - a redução das desigualdades sociais e a erradicação da pobreza, não pode comportar soluções individualizadas [...]. Exatamente por isso é que se criticam algumas soluções isoladas adotadas pelo Poder Judiciário, que, ao conceder benefícios individuais - mesmo que a pretexto de consagrar direitos sociais -, acabam por transformar políticas públicas em políticas individuais, de gozo privado, e não pela parcela socialmente mais fragilizada da sociedade" (SCAFF, Fernando Facury. Orçamento republicano e liberdade igual: ensaio sobre Direito Financeiro, República e Direitos Fundamentais no Brasil. Belo Horizonte: Fórum, 2018, p. 319).

32 No estado do Rio de Janeiro, ocorreu um dos casos mais emblemáticos de conflito entre poderes em matéria de gestão orçamentária, sendo que a grave crise financeira corroeu as relações entre o Governo e o Tribunal de Justiça do Estado. Tudo se iniciou com o atraso no repasse de duodécimos do Poder Judiciário por parte do Governo do Estado, o que resultou na impetração do Mandado de Segurança (MS) 34483/RJ por parte do Tribunal em 2016. Concedida a liminar pelo STF, houve a autorização, no entanto, de que o repasse pudesse sofrer um desconto uniforme de $19,6 \%$ da receita corrente líquida em razão da queda da arrecadação. A ADPF 405/RJ, ajuizada pouco após o writ, relata uma situação de puro caos na gestão financeira do Estado. Nessa época, uma série de bloqueios judiciais nas contas do Estado foram efetuadas para pagamento de pessoal, dentre eles: $\mathrm{R} \$ 1$ 1.600.000.000,00 (um bilhão e seiscentos milhões de reais); $R \$$ 49.211.075,58 (quarenta e nove milhões, duzentos e onze mil, setenta e cinco reais e cinquenta e oito centavos); R\$146.421.219,83, (cento e quarenta e seis milhões, quatrocentos e vinte e um mil, duzentos e dezenove reais e oitenta e três centavos); e $\mathrm{R} \$$ 61.585.849,99 (sessenta e um milhões, quinhentos e oitenta e cinco mil, oitocentos e quarenta e nove reais 
Normas de Direito Brasileiro (após a lei federal n. 13.655/2018) determina em seu artigo 22 que: "Na interpretação de normas sobre gestão pública, serão considerados os obstáculos e as dificuldades reais do gestor e as exigências das políticas públicas a seu cargo, sem prejuízo dos direitos dos administrados".

Na efetivação de políticas públicas, magistrados de primeiro grau possuem dificuldades em enxergar tendências regionais (execução de políticas que acontecem em mais de uma comarca) - capacidades que os gestores públicos estaduais e federais possuem. Os gestores, no entanto, não conseguem enxergar como as deficiências do sistema afetam o jurisdicionado singularmente considerado cotidianamente - fatos que juízes, defensores e assistentes sociais conseguem perceber com mais facilidade.

Para se ter uma melhor noção, deve-se entender como o gestor observa a execução orçamentária de política pública de saúde. Inicialmente, esclarece-se que um gestor público precisa monitorar as atividades e insumos de determinado programa orçamentário, incluindo: os inputs (gastos usados para produzir produtos e serviços); outputs (quantidade e qualidade de bens e serviços públicos produzidos e acesso a tais bens e serviços a curto prazo); outcomes (consequências de médio para longo prazo para os usuários da provisão de serviços públicos ou progresso na consecução dos objetivos do programa); impacto (metas do programa ou consequências de longo prazo da provisão de serviços públicos); e alcance (pessoas que se beneficiam ou são prejudicadas por um programa) ${ }^{33}$.

Se entendermos os outputs (produtos e serviços fornecidos a curto prazo) como medicamentos, tratamentos, cirurgias, número de médicos em determinada área e instalações físicas, o magistrado terá uma compreensão das falhas nos outputs e do alcance dos programas na vida dos jurisdicionados de sua comarca por meio das ações judiciais. Os outcomes, que seriam a redução da mortalidade infantil, redução do número de internações, redução no número de doenças infecciosas, entre outros, e os impactos (melhoria na qualidade de vida dos jurisdicionados e aumento do IDH local) não são sentidos pelo magistrado em sua atividade judicante (talvez sinta em sua vida privada, mas de forma bem discreta).

Essas metas de médio e longo prazo conseguem ser monitoradas por gestores públicos, mas não por magistrados. Quando um magistrado bloqueia valores ou determina o fornecimento de um tratamento de alto custo (sem registro na ANVISA ou substituto de medicamento já fornecido pelo SUS), para um jurisdicionado individualmente

e noventa e nove centavos). Segundo o ministro Luis Roberto Barroso, a utilização de liminares virara: "[...] uma corrida maluca em que recebia quem chegasse primeiro no guichê". A medida cautelar da ADPF for parcialmente concedida para suspender inúmeros bloqueios judiciais nas contas dos Estado por parte de órgãos de primeira e segunda instâncias do TJ-RJ e TRT da 1a Região.

33 SHAH, Anwar. A Practitioner's Guide to Intergovernmental Fiscal Transfers. In: SHAH, Anwar; BOADWAY, Robin. Theory and Practice of Intergovernmental Transfers: principles and practice. The International Bank for Reconstruction and Development. The World Bank. Washington, DC. 2007. p. 11. 
considerado, ele diminui os valores dos inputs, prejudicando os serviços e estoque de medicamentos de toda uma coletividade. O juiz pode, no entanto, apontar aquelas faIhas no fornecimento de serviços e bens que eram para ser fornecidos normalmente pelo SUS e constam do planejamento.

Se, por um lado, o Estado não pode alegar vagamente a teoria da reserva do possível contra a efetivação de direitos sociais fundamentais inseridos no chamado "mínimo existencial", pelo outro, o magistrado não deve fornecer todo e qualquer tratamento médico com fundamento abstrato na tutela da dignidade pessoa humana. Questões técnicas da área da saúde e da gestão pública devem ser consideradas. Com o escopo de combater tais tipos de decisões, o art. 20 da LINDB estabelece: "Nas esferas administrativa, controladora e judicial, não se decidirá com base em valores jurídicos abstratos sem que sejam consideradas as consequências práticas da decisão"34.

$\mathrm{O}$ art. 20 não veda que a decisão seja fundada em valores abstratos, mas exige do magistrado um processo de sua concretização que necessariamente observe as circunstâncias verificadas no mundo dos fatos ${ }^{35}$. Pode-se, logo, fundamentar decisões de direito à assistência à saúde com base no princípio da dignidade da pessoa humana, mas sem deixar de considerar os limites orçamentários e as dificuldades da gestão pública da saúde.

Em sentido parecido, o art. 22 da Lei de Introdução de Normas de Direito Brasileiro ${ }^{36}$ estabelece: “Na interpretação de normas sobre gestão pública, serão considerados os obstáculos e as dificuldades reais do gestor e as exigências das políticas públicas a seu cargo, sem prejuízo dos direitos dos administrados". Essa não consideração de obstáculos reais do gestor na área da saúde é bem recorrente. ${ }^{37}$

Há que se ter certo cuidado, no entanto, quando se lida com a questão das capacidades institucionais para defender que o Poder Judiciário não é a instituição mais adequada para resolver questões de alta complexidade em determinadas áreas da

34 BRASIL. Lei $n^{\circ}$ 13.655, de 25 de Abril de 2018. Altera o Decreto-Lei n 4.657, de 4 de setembro de 1942 (Lei de Introdução às Normas do Direito Brasileiro), e inclui disposições sobre segurança jurídica e eficiência na criação e na aplicação do direito público. Disponível em: <https://presrepublica.jusbrasil.com.br/legislacao/571256856/lei-13655-18>. Aceso em: 19 dez. 2018.

35 JUSTEN FILHO, Marçal. Art. 20 da LINDB - Dever de transparência, concretude e proporcionalidade nas decisões públicas. Revista de Direito Administrativo, Rio de Janeiro, nov. 2018, p. 25.

36 BRASIL. Decreto-lei n 4.657, de 4 de setembro de 1942. Lei de Introdução às normas do Direito Brasileiro. Disponível em: <http://www.planalto.gov.br/ccivil_03/decreto-lei/del4657compilado.htm>. Acesso em: 15 dez. 2018.

37 Nas palavras de Eduardo Jordão: "O combate à idealização dos fatos [...]. Um bom exemplo é o da judicialização da saúde, em que brados do 'direito à saúde' tem para muitos operadores do direito mais relevância do que as condições materiais para implementá-lo. Chega-se mesmo a defender que estas condições materiais são juridicamente irrelevantes e que o operador do direito não deve se preocupar com elas. Os resultados são liminares para concessão de tratamentos caros, que impactam o orçamento governamental de maneira significativa - e prejudicam o próprio oferecimento de outros tratamentos médicos para outros cidadãos" (JORDÃO, Eduardo. Art. 22 da LINDB - Acabou o romance: reforço do pragmatismo no direito público brasileiro. Revista de Direito Administrativo, Rio de Janeiro, nov. 2018, p. 69). 
ciência e de gestão pública. O uso da teoria da reserva do possível não pode se prestar a manter o estado de inefetividade dos direitos fundamentais e indefinição em torno dessas questões inéditas ou complexas ${ }^{38}$.

\subsection{Necessário diálogo equilibrado entre as instituições}

Qual seria o poder com as melhores condições para responder a casos difíceis? A resposta está no diálogo entre instituições. A construção do conhecimento jurídico deve ser realizada por meio de um diálogo contínuo entre todos aqueles agentes que se encontram envolvidos em sua produção e revisão. Havendo uma justificável preocupação no aumento da legitimação das decisões proferidas pelos poderes da república, a aceitação da complexidade dos litígios é uma postura coerente com a proposição de diálogos intra e interinstitucionais - edificando um Estado Democrático de Direito ${ }^{39}$.

A teoria do diálogo entre instituições possui o escopo de enfatizar a função ocupada pela fiscalização constitucional realizada pelos magistrados ${ }^{40}$. A produção do sentido da Constituição é uma tarefa que envolve a colaboração de outros agentes políticos para além do Judiciário. Com a agregação de conhecimentos advindos de diferentes fontes (e de diferentes ciências), a dificuldade contramajoritária seria atenuada, visto que os outros poderes e o próprio povo seriam partícipes na construção do significado constitucional. O diálogo é uma manifestação do equilíbrio entre poderes e a garantia de que os agentes públicos legitimados pelo voto - que precisam periodicamente prestar contas de suas atividades para seus eleitores - respondam às decisões judiciais com as quais eles não concordam. A premissa de que a última palavra se torna relativa está pautada pela possibilidade de os poderes submetidos à accountability disputem o espaço político eventualmente ocupado pelo Judiciário ${ }^{41}$.

Daí o motivo para refletir-se acerca do Judiciário como detentor da palavra definitiva, evitando a imobilização e a manutenção de uma situação injustificável ou de um "direito de errar por último"42. Se por um lado, há a demanda para que os parlamentares

38 Apostas romantizadas em qualquer um dos ramos dos poderes (ou mesmo no "povo") implicam no esquecimento dos problemas que podem assolar qualquer uma das instituições em questão (CLĖVE, Clèmerson Merlin; LORENZETTO, Bruno Meneses. Diálogos institucionais: estrutura e legitimidade. Revista de Investigações Constitucionais, v. 2, n 3, 2015, p. 164).

39 Ibid., p. 164-165.

40 A teoria nasceu no Canadá, tendo como pano de fundo a relação entre Poderes Legislativo e Judiciário enquanto intérpretes da Constituição e dos direitos fundamentais (HOGG, Peter W.; BUSHELL, Allison A. The Charter Dialogue between Courts and Legislatures (Or Perhaps the Charter of Rights Isn't Such a Bad Thing after All). Osgoode Hall Law Journal, v. 35, n. 1, p. 75-124, 1997. p. 105).

41 CLÈVE, Clèmerson Merlin; LORENZETTO, Bruno Meneses. Diálogos institucionais: estrutura e legitimidade, op. cit., 2015, p. 197.

42 "Errar por último" da forma como relata Robert M. O’Neil citando o Chief Justice Charles Evans Hughes da Suprema Corte Americana: "Não somos a instância final em razão da infalibilidade; ao contrário, somos infalíveis em razão de sermos a última instância" (O'NEIL, Robert M. apud VERONESE, Alexandre et al. Vida de 
observem os direitos fundamentais na formulação de seus projetos legislativos, por outro, os juízes devem responder aos conflitos que lhes são apresentados de maneira dialógica e democrática ${ }^{43}$.

O equilíbrio entre poderes é necessário igualmente na definição do que seria um devido processo legal, na seara judicial ou na seara administrativa. Nos Estados Unidos, por exemplo, discutem-se quais parâmetros de autocontenção do Poder Judiciário devem ser adotados perante regulamentos administrativos procedimentais. Há quem defenda que os tribunais devam dar deferência aos julgamentos e procedimentos de agências reguladoras e órgãos administrativos em questões de devido processo legal, exceto nos casos de arbitrariedades. Isso porque tais agências e órgãos estão posicionados melhor para prescrever determinadas normas procedimentais do que os tribunais ${ }^{44}$. Por outro lado, há quem acredite que a independência do Poder Judiciário não deveria ser desafiada, devendo as cortes, dentro de suas próprias interpretações constitucionais, fazer uma interpretação restritiva do devido processo legal nos procedimentos administrativos. Dentro dessa vertente, seria desejável que o Judiciário deixasse a maioria das escolhas procedimentais aos ramos políticos ${ }^{45}$.

A judicialização da assistência à saúde, portanto, passa a exigir um diálogo intra e extraprocessual entre diversas instituições e atores, sendo que novos desenhos procedimentais são formulados para lidar com a especificidade e complexidade desses problemas.

\section{CONVENÇÃO PROCESSUAL, LINDB E OS PARÂMETROS PARA DECISÕES JUDICIAIS CONFORME NORMAS DE GESTÃO PÚBLI- CA}

Uma das mais notáveis novidades do Código Processual Civil de 2015 é a previsão de negócios jurídicos processuais atípicos (ou convenções processuais atípicas). Previu-se a possibilidade de alteração do procedimento para ajustá-lo ao direito material discutido na causa e convencionar sobre os seus ônus, poderes, faculdades e deveres processuais, antes ou durante o processo. Cuida-se de um mecanismo autocompositivo cujo objeto é a flexibilização do procedimento.

\footnotetext{
assessor: as funções de assessoria judiciária em tribunais superiores no Brasil e nos Estados Unidos em perspectiva comparada. Revista Semestral do Departamento e do Programa de Pós-Graduação em Sociologia da UFSCar, v. 7, n², 2017, p. 381).

43 Em razão da necessidade de segurança jurídica e durabilidade das decisões para questões constitucionais, precisa-se considerar a necessidade da continuidade de amplo diálogo entre os ramos do poder e o povo, mantendo os espaços públicos de deliberação (CLÈVE, Clèmerson Merlin; LORENZETTO, Bruno Meneses. Diálogos institucionais: estrutura e legitimidade, op. cit., p. 202).

44 VERMEULE, Adrian. Deference and Due Process. Harvard Law Review, v. 129, 2015, p. 1931.

45 LEVIN, Ronald M. Administrative Procedure and Judicial Restraint. Harvard Law Review, v. 129, p. 338-349, 2016. p. 346.
} 
Os institutos autocompositivos presentes no processo civil (negociação, conciliação e mediação) são meios capazes de tratar e resolver conflitos pela pacificação social, aproximando as partes e afastando o modo tradicional de pensar jurídico-formalista. Não se trata somente de práticas de ganhar ou perder demandas judiciais ${ }^{46}$. Ao se ampliar os meios autocompositivos de negociação, conciliação e mediação, políticas públicas de harmonização entre poderes de estado tornam os cidadãos mais preparados para enfrentarem a complexidade dos conflitos da sociedade moderna ${ }^{47}$.

Seguindo essa tendência de meios autocompositivos, estabeleceu-se, no art. 190 do CPC/2015, o modelo da flexibilização voluntária do procedimento (cláusula geral de negócio jurídico processual ${ }^{48}$, possibilitando o ajuste do rito às peculiaridades da causa. ${ }^{49}$

Inspirado no contratualismo processual, o dispositivo permite uma adequação do instrumento estatal de solução de litígios aos interesses das partes e ao direito material que os consubstanciam. De acordo com a norma, a alteração procedimental só pode ser realizada quando a causa versar sobre direitos que admitam autocomposição e as partes forem plenamente capazes. A modificação deve ser realizada mediante consenso das partes ${ }^{50}$. A flexibilidade procedimental das convenções processuais é medida para aprimorar o direito processual brasileiro.

As regras de forma devem ser moldadas judicialmente quando sua utilização inviabiliza os fins do processo. Regras procedimentais não são um fim em si mesmas. A segurança e a previsibilidade do sistema são garantidas pelo conhecimento prévio das regras do jogo e não pela rigidez do procedimento. Isso porque a flexibilização pode se dar com plena participação e ciência das partes, ainda que as regras não sejam cogentes e tampouco pré-estabelecidas ${ }^{51}$.

46 RIBAS, Lídia Maria; COSTA, Thaise Graziottin Inovação na Jurisdição Estatal: de Contenciosa para uma Jurisdição Singular, Compartilhada, Efetiva, Democrática e Emancipatória. Conpedi Law Review, v. 3, n 1, 2017. p. 210-211.

47 RIBAS, Lídia Maria; GOUVEIA, Jorge Bacelar. Os conflitos nas sociedades brasileira e portuguesa do Século XXI. THEMIS: Revista da Faculdade de Direito da UNL, 2015, p. 18-19.

48 GAJARDONI, Fernando da Fonseca; SOUZA, Maurício Bearzotti de. Os princípios da adequação, da adaptabilidade e da flexibilização procedimental pelo juiz no Novo CPC. Revista do Tribunal Superior do Trabalho, v. 82,2016, p. 177.

49 Conforme o art. 190 do Código de Processo Civil de 2015: "Art. 190. Versando o processo sobre direitos que admitam autocomposição, é lícito às partes plenamente capazes estipular mudanças no procedimento para ajustá-lo às especificidades da causa e convencionar sobre os seus ônus, poderes, faculdades e deveres processuais, antes ou durante o processo. Parágrafo único. De ofício ou a requerimento, o juiz controlará a validade das convenções previstas neste artigo, recusando-lhes aplicação somente nos casos de nulidade ou de inserção abusiva em contrato de adesão ou em que alguma parte se encontre em manifesta situação de vulnerabilidade". (BRASIL. Lei n 13.105, de 16 de março de 2015. Novo Código de Processo Civil. Disponível em: <http://www.planalto.gov.br/ccivil_03/_ato2015-2018/2015/lei//13105.htm>. Acesso em: 22 dez. 2018).

50 DONIZETTI, Elpídio. Curso Didático de Direito Processual. 19a. ed. São Paulo: Gen, 2016, p. 448.

51 GAJARDONI, Fernando da Fonseca. Flexibilidade procedimental: um novo enfoque para o estudo do procedimento em matéria processual. Tese (doutorado em direito processual) - Faculdade de Direito, Universidade de São Paulo, São Paulo, 2008, p. 246. 
O processo deve ser visto como relação jurídica e como instrumento essencial para a democracia. Para isso, o processo deve ser legítimo. O processo deve legitimar-se pela participação das partes, pelo procedimento adequado à tutela dos direitos fundamentais (materiais ou processuais) e ainda produzir uma decisão legitima ${ }^{52}$. Nesse sentido, as convenções processuais podem servir como instrumento de diálogo entre instituições, moldando o procedimento ao direito fundamental de caráter social discutido nos autos.

Em relação à Fazenda Pública, para retirar qualquer dúvida a respeito da possibilidade de autocomposição, o art. 26 da LINDB (incluído pela Lei n. 13.655/2018) permitiu a celebração de acordos pelo Poder Público para "eliminar irregularidade, incerteza jurídica ou situação contenciosa na aplicação do direito público" e "presentes razões de relevante interesse geral", relativizando o princípio da indisponibilidade do interesse público ${ }^{53}$.

Por que não utilizar a lei como instrumento de diálogo?

Fala-se em princípio da adequação para designar a imposição sistemática dirigida ao legislador federal e estadual para que construa modelos procedimentais aptos à tutela especial de certas partes ou do direito material. Fala-se em princípio da adaptabilidade (ou da elasticidade processual) para designar a atividade de flexibilizar o procedimento inadequado ou de reduzida utilidade para melhor atendimento das peculiaridades da causa ${ }^{54}$. Nota-se que o procedimento adequado também pode ser obtido por meio do processo legislativo democrático.

A utilização da lei, no entanto, pode não fornecer o efeito de adaptabilidade necessária e causar distorções que só possam ser corrigidas por novo processo legislativo, geralmente mais rígido e moroso que os acordos processuais. A lei, por sua natureza, não possui a mesma flexibilidade procedimental das convenções processuais. Outra questão diz respeito ao pacto federativo, não havendo segurança jurídica para os Estados-membros legislarem sobre matéria procedimental em razão de um histórico do

52 Dentro do estado constitucional, o direito ao procedimento adequado à tutela do direito material reforça a ideia de acesso à justiça - vinculando o procedimento à proteção dos direitos humanos fundamentais. O procedimento, quando adequado aos valores fundamentais cuja tutela é buscada no processo, integra o processo na dimensão do estado constitucional. Rejeita-se, portanto, a neutralidade do procedimento da mesma forma que se rejeita a neutralidade do processo como mera relação jurídica. (MARINONI, Luiz Guilherme. Da teoria da relação jurídica processual ao processo civil do estado constitucional. Revista Jurídica. Sapucaia do Sul, RS: Notadez, n. 347, set./2006, p. 280).

53 Segundo Sérgio Guerra e Juliana de Palma: "A Lei n 13.655/2018 consagra a dinâmica de atuação consensual ao estabelecer permissivo genérico para que toda a Administração Pública, independentemente de lei ou regulamento específico, celebre compromissos. Também confere importantes diretrizes para uma prática consensual com negociação mais pública e paritária, visando ao efetivo atendimento de interesses gerais. Assim, trabalha para o desenvolvimento da consensualidade administrativa com maior efetividade e segurança jurídica" (GUERRA, Sérgio; DE PALMA, Juliana Bonacorsi. Art. 26 da LINDB-Novo regime jurídico de negociação com a Administração Pública. Revista de Direito Administrativo, p. 135-169, 2018. p. 140).

54 GUERRA, Sérgio; DE PALMA, Juliana Bonacorsi. Art. 26 da LINDB-Novo regime jurídico de negociação com a Administração Pública. Revista de Direito Administrativo, p. 135-169, 2018, p. 154. 
Supremo Tribunal Federal de privilegiar a União nos conflitos de matérias de legislação concorrente ${ }^{55}$.

Há quem defenda que todas as normas procedimentais editadas pela União após 1988 que ultrapassam os limites da generalidade, excedendo a disciplina dos sujeitos, objeto ou forma mínima do rito, ou disciplinando por inteiro a maneira de ser praticado o ato processual não são gerais, e, como tais, inconstitucionais ${ }^{56}$.

Além das questões citadas, a adequação promovida pelas convenções processuais pode ser mais vantajosa em razão do maior debate entre as instituições envolvidas e diretamente interessadas: Poder Judiciário, órgãos de advocacia pública, secretarias, Ministério Público, Defensoria Pública etc. Reconhece-se, no entanto, que há limites que somente a lei poderia transpor, sendo vedado aos acordos processuais como: previsão de hipóteses recursais, prazos recursais, dispensas de remessa necessária, dispensa de oitiva de Ministério Público em casos que a lei prevê que são obrigatórias etc. Há ainda doutrina que delineia limites das convenções processuais conforme o conteúdo dos direitos fundamentais discutidos ${ }^{57}$.

Nessa ideia de procedimento adequado à tutela do direito material, convenções processuais coletivas são formuladas para adequar o processo civil às demandas da saúde. Convenções processuais configuram simultaneamente instrumentos de procedimento adequado às tutelas de direito fundamental à saúde e formas de diálogo entre instituições democráticas.

55 Em matéria de direito processual, o caso que retrata bem essa posição do Supremo refere-se aos limites do art. 24, X, da CF. Explica Remolo Letteriello: "No habeas Corpus n 71.713-PB, o Supremo decidiu pela inconstitucionalidade de um dispositivo da lei paraibana - o art. 59, que definia os crimes de menor potencial ofensivo. Naquele julgamento, concluíram os eminentes Ministros que os Estados estavam impedidos de legislar sobre 'processo penal' e 'competência dos juizados especiais'. Algum tempo depois, em fevereiro de 1996, quando já vigorava a Lei 9.099, o mesmo Supremo, apreciando o Habeas Corpus n 72.930, de Mato Grosso do Sul, reconheceu a inconstitucionalidade de vinte e seis artigos da nossa lei" (LETTERIELLO, Rêmolo. Mato Grosso do Sul: onde nasceram os juizados especiais. Tribunal de Justiça. Poder Judiciário. Mato Grosso do Sul. 2005, p. 3. Disponível em: <http://tjms.jus.br/juizados/doutrina/DTR_20050607181401.pdf> Acesso em: 13 mar. 2019.).

56 GAJARDONI, Fernando da Fonseca. Flexibilidade procedimental: um novo enfoque para o estudo do procedimento em matéria processual, op. cit., p. 245. Seguindo uma linha de raciocínio parecida, há quem defenda que são inconstitucionais os limites impostos de remessa necessária do $§ 3$ do artigo 496 do Código de Processo Civil de 2015 por violarem o pacto federativo (MASCARENHAS, Caio Gama. Inconstitucionalidade da dispensa econômica de remessa necessária do CPC. Revista Eletrônica de Direito Processual, v. 19, n. 3, 2018, p. 157-162).

57 Luiz Filipe de Araújo Ribeiro defende, por exemplo, que negócios processuais devem passar pelo filtro interpretativo dos direitos fundamentais. Propõe a análise dos limites por meio de um método composto de três fases: na primeira, analisa-se o objeto tutelado pelo direito fundamental; na segunda, analisa-se a intervenção estatal; por fim, analisa-se a possibilidade de justificação da intervenção em face da aplicação de um limite constitucional (RIBEIRO, Luiz Filipe de Araújo. Negócios processuais e seus limites a partir da teoria liberal dos direitos fundamentais. Dissertação (mestrado em direito constitucional) - Universidade Federal do Rio Grande do Norte, Natal, 2017, p. 98). 


\subsection{Os acordos processuais coletivos ou protocolos institucionais}

Na seara dos acordos processuais coletivos, há aqueles destinados a disciplinar o procedimento civil e aqueles voltados à administração judicial. No caso das convenções destinadas a regulamentar o procedimento civil, os acordos funcionam como um instrumento de gestão coletiva dos processos. No segundo caso, trata-se de um instrumento de política pública da justiça.

Os acordos coletivos de procedimento civil são celebrados entre o Poder Judiciário, Poder Executivo, Ministério Público, advogados públicos e privados ou peritos, buscando suprir lacunas ou dificuldades hermenêuticas encontradas na lei quanto a regras procedimentais. Esses acordos aproximam a lei da realidade e, ao permitir a participação social na composição do procedimento judicial, legitimam a atuação do juiz. Já os acordos coletivos de administração judicial voltam-se a finalidades tais como garantir o controle de gastos e de prazos judiciais; organizar a comunicação eletrônica processual e, até mesmo, no âmbito penal; e organizar a prevenção e a luta contra a delinquência ${ }^{58}$.

Ressalta-se que convenções coletivas processuais também podem ser chamadas de protocolos institucionais. Elas podem servir como importante instrumento de exercício da consensualidade em sede processual, superando dificuldades práticas e operacionais em prol de uma gestão processual coletiva mais eficiente. Observado o regime jurídico distinto a que se submetem os entes públicos na negociação processual, as possibilidades de sua utilização são variadas ${ }^{59}$. Há a possibilidade inclusive de se elaborar protocolos acerca de fornecimento de determinados medicamentos ${ }^{60}$.

Existe a possibilidade de celebração, pelo Estado, de inúmeras convenções processuais atípicas, com o escopo de atingir várias relações jurídicas processuais e pré-processuais entre os administrados e a Administração Pública. A convenção processual coletiva mais famosa, no âmbito dos estados, é a instalação de núcleos de assistência técnica da saúde em todos os processos judiciais que versam sobre demandas de saúde (NATjus) $^{61}$.

58 BARREIROS, Lorena Miranda Santos. Convenções processuais e poder público. Tese (doutorado em direito público) - Faculdade de Direito, Universidade Federal da Bahia, Salvador, 2016, p. 146.

59 BARREIROS, Lorena Miranda Santos. Convenções processuais e poder público. Tese (doutorado em direito público) - Faculdade de Direito, Universidade Federal da Bahia, Salvador, 2016, p. 387.

60 Segundo Lorena Miranda Santos Barreiros: "Imagine-se, por exemplo, que o Poder Público, por sua unidade integrada ao Sistema Único de Saúde, passe a fornecer um determinado medicamento $X$, antes por ele não disponibilizado. Inúmeros processos que se refiram àquela temática (fornecimento do medicamento $\mathrm{X}$ ) poderão estar em tramitação no momento em que o ente público passe a fornecer o fármaco. Em diversos deles, poderá haver a cumulação do pedido de obtenção do medicamento com o pedido de danos morais, este não reconhecido pelo ente público" (Ibid., p. 385).

61 Esses núcleos possuem por finalidade assessorar o Poder Judiciário com informações técnicas nas demandas relativas ao fornecimento de medicamentos, exames, internações, cirurgias e demais tratamentos em face do Sistema Único de Saúde (SUS). Usualmente, os núcleos manifestam-se nas demandas de prestações de 
Há casos de convenções específicas em relação a determinados tratamentos. Nesse sentido, ressaltam-se casos de convenções processuais na área da saúde em âmbito pré-processual ou pós-processual, sem a interferência do Poder Judiciário - que poderá, no entanto, fazer o controle de validade da convenção. Pode-se estipular prazos, procedimentos administrativos e atribuições institucionais para cumprimento de decisões de determinado tratamento cirúrgico por meio de termo de cooperação técnica entre Secretaria do Estado de Saúde, Secretaria Municipal de Saúde, Defensoria Pública, Ministério Público ${ }^{62}$.

Essas convenções (NATs e específicas) configuram uma primeira fase dos diálogos entre as instituições em matéria de saúde pública. Nota-se ainda que as deliberações dos NATs seguem determinados padrões de uniformização. Alguns elementos utilizados por esses núcleos em suas deliberações foram posteriormente aceitos pelo Superior Tribunal de Justiça no REsp 1657156/RJ (precedente vinculante) como, por exemplo, o registro na ANVISA e a preferência de fornecimento de medicamentos já oferecidos pelo SUS.

Há a necessidade, no entanto, de avançar nos diálogos e aprimorar as convenções processuais entre os poderes da república em matéria de saúde. Isso porque o sistema processual ainda é insuficiente e inadequado para dar respostas mínimas aos problemas de judicialização da saúde.

Um desafio proposto aqui é utilizar convenções processuais na área da saúde pública como forma de aproximar o direito processual do direito administrativo. Deve-se colocar o magistrado mais próximo do gestor público em uma relação de diálogo e equilíbrio e não em uma relação de poder, em que um se sobrepõe ao outro. Deve-se

saúde em face do Sistema Único de Saúde (SUS), fornecendo elementos técnicos aos juízes no momento da decisão. A composição do NAT e suas normas de financiamento e operação geralmente são estipuladas por meio de convênios entre Poder Judiciário e Poder Executivo de um ou mais entes federativos (estados, municípios e União). Nota-se que o regulamento do NATjus geralmente abrange todas as ações ajuizadas contra o SUS, sem distinção. No âmbito do Tribunal de Justiça do mato Grosso do Sul, por exemplo, as atividades do Núcleo de Apoio Técnico (NAT) são regulamentadas pela Portaria n 881, de 12 de fevereiro de 2016. Segundo o art. $3^{\circ}$ de tal portaria normativa, é atribuição do NAT manifestar-se previamente em todas as ações judiciais cujas pretensões pleiteadas sejam prestações de saúde em face do Sistema Único de Saúde (SUS). Ressalta-se que análise feita por tal núcleo é meramente documental, sem qualquer contato direto com o paciente (MATO GROSSO DO SUL. Tribunal de Justiça do Estado do Mato Grosso do Sul. Portaria nº 881 de 12 de fevereiro de 2016. Aprova o Regulamento Interno do Núcleo de Apoio Técnico - NAT. Disponível em: <https://www.tjms. jus.br/_estaticos_/nat/Portaria_NAT.pdf>. Acesso em: 19 maio 2019).

62 Um exemplo é o Termo de cooperação técnica n 01/2017-MPF/PR/MS/GABPRDC realizado no Mato Grosso do Sul, em que a Secretaria do Estado de Saúde, Secretaria Municipal de Saúde de Campo Grande/MS, Hospital Universitário da UFMS, Defensorias Públicas da União e do Estado, Ministérios Públicos Estadual e Federal estipularam várias cláusulas acerca da realização de cirurgias ortopédicas em cumprimento de decisões liminares (MATO GROSSO DO SUL. Tribunal de Justiça do Estado do Mato Grosso do Sul. Termo de cooperação técnica n. 01/2017-MPF/PR/MS/GABPRDC. Estipula cláusulas para execução de cirurgias ortopédicas em cumprimento de decisões judiciais. Convenção processual disponível em: <https://www.tjms.jus.br/_estaticos_/ nat/termo_cooperacao_tecnica_mpf.pdf>. Acesso em: 19 maio 2019.). 
efetivar o art. 22 da Lei de Introdução de Normas de Direito Brasileiro, que exige a consideração dos obstáculos e as dificuldades reais do gestor e as exigências das políticas nas decisões judiciais e administrativas.

Tal tentativa não pode ser interpretada como um salvo-conduto para que os negócios processuais coletivos possam ocorrer sem qualquer espécie de controle judicial. Ao contrário, destaca-se a essencialidade do papel do Estado-juiz na função de controle dos pressupostos de existência, validade das convenções processuais nos casos concretos, de modo a evitar a violação dos direitos fundamentais. Para tanto, adverte-se que a intervenção estatal na área de proteção sempre deverá ter a respectiva justificativa constitucional devidamente fundamentada ${ }^{63}$.

Antes de se propor novos parâmetros para as convenções processuais, os limites estipulados pela doutrina ao conteúdo de tais acordos devem ser avaliados. Segundo Lorena Miranda Santos Barreiros ${ }^{64}$ :

Na celebração de protocolos institucionais, ao menos três pontos devem ser especialmente observados: a) o acordo não pode ocasionar prejuízo a terceiro ou lhe impor ônus ou dever não decorrentes de lei (limite, aliás, aplicável a qualquer convenção processual, envolva ou não o Poder Público); b) o protocolo institucional não pode prejudicar o adequado desenvolvimento do serviço jurisdicional ou prejudicar o interesse público, devendo ser particularmente sopesadas as suas vantagens e desvantagens quando acarretem acréscimo de gastos públicos; c) a convenção coletiva em questão não pode violar a independência funcional dos magistrados.

Nota-se que, de maneira direta ou indireta, todos os requisitos dos protocolos institucionais estão relacionados com defesa dos seguintes preceitos: direito material do administrado; a garantia de acesso à justiça e do devido processo legal; e o poder geral de cautela do magistrado. Pode-se dizer que as convenções processuais não podem afetar os poderes e deveres do juiz ${ }^{65}$ nem violar as garantias constitucionais do processo $^{66}$.

63 RIBEIRO, Luiz Filipe de Araújo. Negócios processuais e seus limites a partir da teoria liberal dos direitos fundamentais. Dissertação (mestrado em direito constitucional) - Universidade Federal do Rio Grande do Norte, Natal, 2017, p. 98.

64 BARREIROS, Lorena Miranda Santos. Convenções processuais e poder público. Op. cit. p. 386.

65 Nesse sentido, enunciado ENFAM n 36: "A regra do art. 190 do CPC/2015 não autoriza às partes a celebração de negócios jurídicos processuais atípicos que afetem poderes e deveres do juiz, tais como os que: a) limitem seus poderes de instrução ou de sanção à litigância ímproba; b) subtraiam do Estado/juiz o controle da legitimidade das partes ou do ingresso de amicus curiae; c) introduzam novas hipóteses de recorribilidade, de rescisória ou de sustentação oral não previstas em lei; d) estipulem o julgamento do conflito com base em lei diversa da nacional vigente; e e) estabeleçam prioridade de julgamento não prevista em lei".

66 É o conteúdo do Enunciado ENFAM n 37: "São nulas, por ilicitude do objeto, as convenções processuais que violem as garantias constitucionais do processo, tais como as que: a) autorizem o uso de prova ilícita; b) limitem a publicidade do processo para além das hipóteses expressamente previstas em lei; c) modifiquem o regime de competência absoluta; e d) dispensem o dever de motivação". 


\subsection{Algumas propostas: acordos processuais coletivos ou protocolos institucionais na seara da gestão pública orçamentária}

Considerando os inúmeros problemas de gestão pública causados pela judicialização da saúde, alguns novos modelos de convenções processuais podem ser pensados. Listam-se alguns:

a) Estabelecimento de parâmetros judiciais orçamentários nos casos de decisões que versem sobre medicamentos de alto custo e cirurgias, com prazos, procedimentos e obrigações recíprocas entre instituições, inclusive o Poder Judiciário;

b) Possibilidade de os bloqueios judiciais afetarem somente um fundo específico baseado no valor global de bloqueios judiciais no exercício financeiro anterior, evitando que se prejudique o planejamento e execução de outras políticas públicas;

c) Criação de NAT de natureza contábil para analisar orçamentos médicos nos casos de cumprimento de decisões judiciais por entidades privadas. Na prática, haveria um faturista de orçamentos médicos apresentados em processos judiciais, podendo haver convênios para treinamento de servidores para tanto. Há o dever de economicidade por parte de todos os poderes da república, seja na execução por via administrativa ou judicial;

d) Previsão de suspensão ou extinção coletiva de ações judiciais que tratem sobre casos de fornecimento de medicamentos, tratamentos e cirurgias posteriormente disponibilizadas e regularizadas pelo poder público;

e) Dever judicial de respeito a contratos administrativos feitos pelo poder público com hospitais e associações médicas em detrimento de clínicas particulares não contratadas para os mesmos tratamentos; $e$

f) Portais da transparência (sítios eletrônicos) com filas de pacientes que aguardam por procedimentos cirúrgicos, valores de bloqueios judiciais, tratamentos e medicamentos não registrados pela ANVISA, valores empregados, empresas beneficiárias, juízo responsável pela decisão, médicos responsáveis pela receita médica etc.

A convenção processual coletiva deve ter um alto grau de persuasão técnica sem que isso interfira no poder geral de cautela do magistrado. $O$ magistrado, no entanto, deverá fundamentar o motivo pelo qual a convenção processual não se aplica ao 
caso (dever de motivação). Caso não se concorde com as razões invocadas pelo magistrado para afastar a convenção, poder-se-á interpor recursos com base na violação do acordo processual.

Em relação ao estabelecimento de prazos mínimos por convenções processuais, Lorena Miranda Santos Barreiros ${ }^{67}$ cita a problemática:

Sob essa última perspectiva é que remanesce dúvida, por exemplo, acerca da possibilidade de celebração de protocolo institucional que objetive estabelecer prazos mínimos para o cumprimento de obrigações de fazer pelos entes públicos, a depender da matéria e do número de litisconsortes existentes em cada processo (evitando-se, assim, as decisões judiciais que determinam o cumprimento imediato da obrigação ou que estipulam prazo desarrazoado para tal atendimento). Muito embora haja uma grande vantagem no estabelecimento de tais prazos, especialmente no que diz respeito ao resguardo da segurança jurídica e da previsibilidade no cumprimento de decisões judiciais, pode-se contrapor a esse argumento o de que um protocolo institucional dessa natureza violaria a independência funcional dos juízes.

Nota-se que a violação da independência funcional dos juízes a que a autora se refere diz respeito à tutela do direito material, ao acesso à justiça e ao poder geral de cautela do magistrado. Uma questão deve ser ressaltada em relação ao estabelecimento de parâmetros judiciais orçamentários e o estabelecimento de prazos: como todo procedimento administrativo, há sempre um determinado grau de burocracia. Não podem os trâmites burocráticos se sobreporem ao direito fundamental à saúde dos administrados, mas igualmente não é toda prestação material de direito à saúde tão urgente que não possa aguardar os trâmites. O que irá determinar, na prática, a natureza de urgência do provimento é o grau de risco envolvido. Enquanto uma cirurgia de caráter eletivo (cirurgia ortopédica ou de caráter estético, por exemplo) pode oferecer um risco menor no decorrer do tempo, a espera por vaga em UTI não comporta maiores dilações temporais em matéria de procedimento ${ }^{68}$.

Partindo de tais premissas, não aparenta ser desproporcional a instituição de prazos e parâmetros orçamentários para decisões judiciais por meio de protocolos

67 BARREIROS, Lorena Miranda Santos. Convenções processuais e poder público, op. cit., p. 386.

68 Sobre os direitos dos administrados quando da interpretação das convenções processuais coletivas, pode-se invocar o art. 22 da LINDB conforme o entendimento de Eduardo Jordão. O autor debruça-se sobre o conflito entre os direitos dos administrados e as dificuldades reais do gestor público: "Pense-se na judicialização da saúde: num contexto real de finitude orçamentária, conceder determinado tratamento médico excessivamente custoso a um cidadão implicará necessariamente o desfalque orçamentário que prejudicará o atendimento a outros direitos de outros cidadãos. Dito de outro modo, haverá quase sempre direitos em conflito - e esta pode, inclusive, ser a 'dificuldade real' enfrentada pelo gestor público no caso concreto. Neste contexto, supor que a lei tenha determinado aprioristicamente que 'direitos não podem ser afetados', independentemente das circunstâncias do caso concreto, simplesmente não é realista, nem é razoável". (JORDÃO, Eduardo. Art. 22 da LINDB - Acabou o romance: reforço do pragmatismo no direito público brasileiro, op. cit., p. 82). 
institucionais. Em relação aos limites dos protocolos institucionais, não se vislumbra quaisquer vícios nas propostas de convenções processuais expostas no início da subseção.

Protocolos institucionais sobre normas orçamentárias e gestão pública impõem ônus ou deveres já previstos na Constituição e em normas infraconstitucionais. No tocante ao devido processo legal (art. 5, LV e LIV, da Constituição; e art. 190 do CPC/2015), as convenções processuais buscam apenas efetivar o direito material a uma política pública efetiva para o maior número possível de usuários conforme um procedimento adequado à tutela do direito fundamental à saúde.

Em relação às normas constitucionais e infraconstitucionais que regem e organizam o SUS, os acordos podem servir para efetivar tais normas (arts. 196 e seguintes da Constituição; e Lei n. 8080/90). As normas de gestão orçamentária, por sua vez, estão previstas nos arts. 163 e seguintes da Constituição Federal e nas leis federais n. 4.320/64 (Lei de Normas erais de Direito Financeiro) e complementar n. 101/2000 (Lei de Responsabilidade Fiscal).

Convenções processuais coletivas sobre normas de gestão orçamentária atendem ao interesse público e auxiliam o adequado desenvolvimento do serviço jurisdicional. Ao prever normas de transparência, responsabilidade fiscal e economicidade à atividade do juiz, a gestão pública pode se articular melhor - inclusive o orçamento das políticas sociais torna-se mais republicano e distribuído de forma mais igualitária entre os administrados. Os custos operacionais seriam, em tese, menores que os benefícios gerados pelos onerosos bloqueios judiciais sem critérios objetivos.

No que diz respeito ao poder geral de cautela do magistrado e o devido processo legal (alguns dos fundamentos da independência funcional), os protocolos buscam efetivar os artigos 20 e 22 da LINDB, que já fixam parâmetros e diretrizes para magistrados quando do julgamento de atos e omissões do poder público em suas políticas econômicas e sociais.

Em relação ao artigo 20 da LINDB (segurança jurídica, transparência e concretude nas decisões judiciais), a decisão fundada em normas gerais e abstratas pressupõe um processo de ponderação de valores indissociável do universo fático existente. Isso implica no dever judicial de observar os impactos concretos de uma decisão, inclusive para evitar a consumação de danos irreparáveis aos próprios valores invocados como fundamento principal de decidir. Sob determinado aspecto, a determinação do art. 20 é apenas uma especificação da regra já contida no art. $5^{\circ}$ da mesma LINDB, que prevê que, "Na aplicação da lei, o juiz atenderá aos fins sociais a que ela se dirige e às exigências do bem comum"69.

69 JUSTEN FILHO, Marçal. Art. 20 da LINDB - Dever de transparência, concretude e proporcionalidade nas decisões públicas, op. cit., p. 23-27. 
O artigo 22 da LINDB (reconhecimento judicial das dificuldades do gestor público), por sua vez, objetiva combater a idealização excessiva dos fatos. A respeito da natureza das dificuldades de gestão que devem ser consideradas pelo magistrado, têm-se citado dificuldades e obstáculos materiais, temporais, orçamentários e de pessoal. Tais circunstâncias, evidentemente, podem impedir a implementação de uma dada política pública Além disso, são exemplos de dificuldades frequentes que a administração pública encontra em todo o país: falta de verbas, tempo escasso para planejar e executar a ação, déficit de pessoal, baixa qualidade dos recursos humanos disponíveis, deficiências de material de escritório, de infraestrutura mínima de trabalho, entre outras ${ }^{70}$.

A questão da transparência da atuação do judiciário nas demandas de saúde merece um tópico à parte. Como todas as normas administrativas e orçamentárias, a utilização de verbas públicas por meio de decisões judiciais necessita maior transparência, não sendo o caráter de publicidade das decisões judiciais suficiente para suprir tal lacuna.

\subsection{Transparência e accountability ${ }^{71}$ de verbas públicas utilizadas nas demandas judiciais contra o SUS}

Transparência administrativa não se confunde com publicidade de atos administrativos e processuais. Embora aquela dependa desta, a publicidade foca-se na disponibilidade pública das informações e atos, enquanto a transparência diz respeito ao direito do cidadão de receber informações de forma clara e compreensível. Nas palavras de Têmis Limberger: “Embora a transparência não seja expressa dentre os princípios que regem a administração pública, a partir dos já enunciados, deles pode-se extrair"72.

A publicidade na administração pública brasileira está estabelecida como princípio no caput do artigo 37 da CF/88. A publicidade de atos judiciais advém do art. 5०, LX, da Constituição, que determina: "A lei só poderá restringir a publicidade dos atos processuais quando a defesa da intimidade ou o interesse social o exigirem". As duas normas, no entanto, possuem o mesmo fundamento e devem ser lidas de forma conjunta.

Em relação à natureza dos interesses tutelados, o princípio da publicidade dos atos processuais atende não só ao interesse das partes (administrador/administrado

\footnotetext{
70 JORDÃO, Eduardo. Art. 22 da LINDB - Acabou o romance: reforço do pragmatismo no direito público brasileiro, op. cit., p. 76.

71 O conceito, cuja palavra não foi traduzida para a língua portuguesa, remete ao princípio de que indivíduos e organizações são responsáveis por seus atos e devem prestar contas dos mesmos (CAVALCANTE, Pedro Luiz Costa. Orçamento por Desempenho: Brasil x EUA - análise qualitativa comparada dos modelos de avaliação dos programas governamentais. REGE. Revista de Gestão USP, 2010, p. 15).

72 LIMBERGER, Têmis. Transparência administrativa e novas tecnologias: o dever de publicidade, o direito a ser informado e o princípio democrático. Revista de Direito Administrativo, v. 244, 2007, p. 262.
} 
ou autor/réu), mas igualmente ao interesse público. A existência do princípio da publicidade processual é baseada na necessidade de controle do processo pelas partes e pela opinião pública. O preceito possui o escopo de proteger as partes de abusos, arbítrios e prepotências dos agentes do Estado. Tal princípio protege igualmente o juiz, ao permitir que a sociedade tenha uma exata noção de sua atuação e, por fim, tutela a coletividade, ao permitir o controle dos atos processuais e sua consonância com os objetivos constitucionais. A publicidade dos atos processuais e a publicidade da atuação da administração pública estão mais voltadas a estabelecer a exigência constitucional de que os poderes públicos socializem informações sobre suas atuações ${ }^{73}$.

A transparência, como princípio da gestão fiscal responsável, pressupõe a publicidade e a compreensibilidade das informações. Nota-se que o princípio da transparência é mais amplo que o da publicidade, visto que a mera divulgação de informações sem tornar o conteúdo compreensível para a sociedade não é transparência, assim como a ausência de informação compreensível sem a necessária divulgação também não é transparência. A transparência na Lei de Responsabilidade Fiscal, por exemplo, aparece como um instrumento para que a sociedade possa tomar conhecimento das contas e ações governamentais ${ }^{74}$. A interdependência entre transparência e efetividade dos direitos humanos fundamentais possui reconhecimento internacional, daí o motivo de constar expressamente da Agenda 2030 de desenvolvimento sustentável da $\mathrm{ONU}^{75}$

Daí o motivo pelo qual faz-se tão necessário um portal da transparência no âmbito da judicialização da saúde, com filas de pacientes que aguardam por procedimentos cirúrgicos, bloqueios judiciais, tratamentos e medicamentos não registrados pela ANVISA, valores empregados, empresas beneficiárias, juízo responsável pela decisão, médicos responsáveis pela receita médica etc.

A população, composta por usuários do Sistema do Sistema Único de Saúde, deve conhecer, opinar e participar do processo de argumentação utilizado pelo juiz, emitindo juízo de valor sobre a destinação das verbas públicas destinadas aos serviços de saúde. Toda vez que um juiz determina o fornecimento ou um tratamento experimental, ou não registrado na ANVISA; ou substitui um medicamento fornecido pelo

73 COPETTI, André. Comentário ao artigo 50, LX. In: CANOTILHO, J. J. Gomes; MENDES, Gilmar F.; SARLET, Ingo W. Comentários à Constituição do Brasil. São Paulo: Saraiva/Almedina, 2013, p. 835.

74 PLATT NETO, Orion Augusto et al. Publicidade e transparência das contas públicas: obrigatoriedade e abrangência desses princípios na administração pública brasileira. Contabilidade Vista \& Revista, v. 18, n. 1 , 2009, p. 80.

75 Destaca-se que o objetivo 16.10 da Agenda 2030 é: "Assegurar o acesso público à informação e proteger as liberdades fundamentais, em conformidade com a legislação nacional e os acordos internacionais" . A importância da relação integral entre o acesso público à informação e o respeito pelos direitos fundamentais não deve ser subestimada. Ambos são princípios que se reforçam mutuamente e foram combinados em um único objetivo unificado nos objetivos de desenvolvimento sustentável (ODS) por boas razões (ORME, Bill. De la regulación a la implementación: políticas de acceso a la información en acción. Cuadernos de Discusión de Comunicación e Información, v. 8, 2017, p. 16-17). 
SUS sem sua comprovação de ineficácia, ele deixa de aplicar normas de caráter sanitário e orçamentário.

Quando afirma que a lei é inadequada para a efetivação de um direito fundamental, o magistrado deve argumentar que a lei interfere sobre o bem jurídico que foi excluído da sua esfera de proteção. Deve o órgão julgador demonstrar, por meio de adequada argumentação, que a lei colide com o direito fundamental e não simplesmente opor o direito fundamental à lei de forma abstrata. Ao afastar uma lei para efetivar um direito fundamental, configura-se uma oposição entre uma argumentação jurisdicional em favor da sociedade e a decisão tomada pelos representantes eleitos pelo povo ${ }^{76}$.

O fato de haver uma infinidade de decisões judiciais públicas sobre assistência à saúde diariamente não significa a existência de transparência. Mesmo podendo acessar grande parte dos processos judiciais, o cidadão comum não consegue saber com clareza como estão sendo efetuados os gastos da judicialização da saúde pública de maneira singular por paciente e global por hospital, empresa farmacêutica, procedimento etc. A sociedade, como beneficiária do SUS, deve possuir acesso a tais informações de forma clara e compreensível.

O Poder Judiciário, além de utilizar critérios técnicos quando da formação da argumentação jurisdicional na área da saúde em cada decisão judicial, deve informar a sociedade e viabilizar sua participação. A judicialização da saúde interfere na gestão de políticas públicas, devendo-se dar publicidade e transparência para as decisões e impactos de forma detalhada e igualmente global. De tal forma, as decisões judiciais passam a ter um maior grau de legitimidade.

As decisões judiciais na área da saúde pública devem ter maior grau de accountability, possibilitando uma melhor auditoria dos bloqueios judiciais, facilitando investigações criminais de atos de corrupção, auxiliando a possibilidade de ações de reparação de danos por parte do poder público e permitindo a restituição de valores por parte de planos de saúde privados. ${ }^{77}$ Um portal da transparência de dados de judi-

\footnotetext{
76 Segundo Marinoni, a argumentação judicial “[...] deve ser capaz de convencer os cidadãos de que a decisão parlamentar, ou a representação política, não deve prevalecer sobre o direito fundamental". (MARINONI, Luiz Guilherme. Da teoria da relação jurídica processual ao processo civil do estado constitucional. Revista Jurídica. Sapucaia do Sul, RS: Notadez, n. 347, set./2006, p. 304).

77 O Supremo Tribunal Federal, quando do julgamento do Recurso Extraordinário n 597064, julgou constitucional a cobrança disciplinada no art. 32 da Lei 9.656/98, ostentando natureza jurídica indenizatória ex lege (receita originária). O ressarcimento previsto na norma do art. 32 da Lei 9.656/98 é aplicável aos procedimentos médicos, hospitalares ou ambulatoriais custeados pelo SUS posteriores a 4.6.1998, desde que assegurado o exercício do contraditório e da ampla defesa, no âmbito administrativo, em todos os interstícios amparados por sucessivas reedições de medidas provisórias. Segundo tal norma: "Serão ressarcidos pelas operadoras dos produtos de que tratam o inciso I e o $\S 1^{\circ}$ do art. 10 desta Lei, de acordo com normas a serem definidas pela ANS, os serviços de atendimento à saúde previstos nos respectivos contratos, prestados a seus consumidores e respectivos dependentes, em instituições públicas ou privadas, conveniadas ou contratadas, integrantes do Sistema Único de Saúde - SUS".
} 
cialização do SUS abre a possibilidade de mapear as deficiências na oferta de serviços de saúde conforme o índice de judicialização em cada região inclusive.

Conquanto a transparência seja um conceito inerente à responsabilização, não se pode entender a lista transparente de bloqueios como violação à independência funcional do magistrado por vários motivos: as verbas bloqueadas do SUS são do erário e assumem regime próprio de transparência; a decisões do judiciário são públicas por natureza; não existe, no Brasil, responsabilização dos juízes pelo conteúdo decisório, mas apenas por infração dos deveres funcionais; e todo poder emana do povo, devendo os atos do poder judiciário passarem pelo crivo democrático.

Não há responsabilização por decisão contramajoritária no Brasil, visto que feriria a independência do Poder Judiciário e, consequentemente, o acesso à justiça. Discute-se a responsabilização por conteúdo decisório ou decisional accountability ${ }^{78}$ nos Estados Unidos da América, mas deve-se considerar que os magistrados estadunidenses são majoritariamente investidos no cargo por meio de eleições. Isso implica que juízes podem não permanecer nos cargos se seus eleitores não estiverem convencidos da justiça de suas decisões judiciais ${ }^{79}$.

A accountability na judicialização da saúde deve abranger aqueles que são intermediários e beneficiários diretos e indiretos das decisões judiciais, considerando os elementos da transparência, da prestação de contas e da responsabilização na gestão das verbas públicas. São intermediários e beneficiários: pacientes, gestores, agentes públicos, empresas de medicamentos, agentes de saúde etc.

Percebe-se, assim, que os negócios jurídicos processuais com normas de gestão pública orçamentária estariam incompletos se não houvesse instrumentos de transparência hábeis para dar publicidade aos atos dos poderes e instituições envolvidas.

\section{CONSIDERAÇÕES FINAIS}

Nota-se que os problemas práticos da judicialização da saúde não se limitam às complexidades próprias da área da saúde, sendo igualmente graves na área de gestão pública orçamentária. Algo é certo: o processo civil, da forma como é utilizado hoje, é incapaz de dar respostas minimamente adequadas aos problemas da gestão pública da saúde.

Com o escopo de fornecer um procedimento adequado à tutela do direito material, convenções processuais coletivas são formuladas para adequar o processo civil às demandas da saúde mediante a flexibilidade própria desses instrumentos. Convenções

$78 \mathrm{GEYH}$; Charles Gardner. Rescuing judicial accountability from the realm of political rhetoric. Case W. Res. L. Rev., v. 56, 2005, p. 922-924.

79 DUBOIS, Philip L. Accountability, independence, and the selection of state judges: The role of popular judicial elections. SW LJ, v. 40, 1986, p. 51-52. 
processuais configuram simultaneamente instrumentos de procedimento adequado às tutelas de direito fundamental à saúde e às formas de diálogo entre instituições democráticas.

Há a necessidade, no entanto, de avançar nos diálogos e aprimorar as convenções processuais entre os poderes da república em matéria de saúde. Isso porque as convenções processuais coletivas existentes, em sua maioria, focam apenas em critérios técnicos da área da saúde, havendo a necessidade de previsão de critérios de gestão pública orçamentária.

Ressalta-se que o foco dos diálogos institucionais não é as instituições, mas a coletividade, que possui o direito a um sistema único de saúde funcional, eficiente e sustentável. A intenção é democratizar e aprimorar o debate de determinadas questões postas em frente ao Poder Judiciário.

O acesso à justiça é uma garantia constitucional contra a síndrome da inefetividade dos direitos sociais. Pelo ponto de vista institucional, no entanto, uma melhor organização da judicialização da saúde pública poderia auxiliar o Estado a regularizar o fornecimento de medicamentos que eram para ser fornecidos pelo SUS e, no entanto, não o foram (embora constantes no planejamento). De uma forma ou de outra, a regularização em tais casos poderia diminuir o número de ações de saúde posteriores que o Judiciário teria que julgar por falha de execução da política pública.

Um desafio proposto aqui é utilizar convenções processuais na área da saúde pública como forma de aproximar o direito processual do direito administrativo. Deve-se colocar o magistrado mais próximo do gestor público em uma relação de diálogo e equilíbrio e não uma relação de poder, em que um se sobrepõe ao outro. Considerando os inúmeros problemas de gestão pública causados pela judicialização da saúde, alguns novos modelos de convenções processuais podem ser pensados no contexto atual.

A lista apresentada ao longo do trabalho é meramente exemplificativa. Mesmo que uma ou outra se mostre de difícil aplicação em determinado contexto fático, é preciso insistir em novos procedimentos para as ações que discutam prestações sociais fornecidas pelo poder público.

\section{REFERÊNCIAS}

AVILA, Ana Paula Oliveira; DE MELO, Karen Cristina Correa. Separação de poderes e diálogos institucionais nos litígios envolvendo o direito à saúde. Revista de Investigações Constitucionais, v. 5, n. 1, p. 83-108, 2018.

BARREIROS, Lorena Miranda Santos. Convenções processuais e poder público. Tese (doutorado em direito público) - Faculdade de Direito, Universidade Federal da Bahia, Salvador, 2016. 
BRASIL. DEPARTAMENTO DE INFORMÁTICA DO SUS (DATASUS). Disponível em: <http://www2. datasus.gov.br/DATASUS/index.php?area=02 >. Acesso em: 21 abr. 2019.

BRASIL. Decreto-lei no 4.657, de 4 de setembro de 1942. Lei de Introdução às normas do Direito Brasileiro. Disponível em: <http://www.planalto.gov.br/ccivil_03/decreto-lei/del4657compilado. htm>. Acesso em: 15 dez. 2018.

BRASIL. Lei n 13.105, de 16 de março de 2015. Novo Código de Processo Civil. Disponível em: < http://www.planalto.gov.br/ccivil_03/_ato2015-2018/2015/lei/l13105.htm>. Acesso em: 22 dez. 2018.

BRASIL. Lei n 13.655, de 25 de Abril de 2018. Altera o Decreto-Lei n 4.657, de 4 de setembro de 1942 (Lei de Introdução às Normas do Direito Brasileiro), e inclui disposições sobre segurança jurídica e eficiência na criação e na aplicação do direito público. Disponível em: < https://presrepublica.jusbrasil.com.br/legislacao/571256856/lei-13655-18>. Aceso em: 19 dez. 2018.

BRASIL. Superior Tribunal de Justiça. REsp 1657156/RJ, Relator: Ministro Benedito Gonçalves, Primeira Seção, julgado em 25/04/2018. Disponível em: <http://www.stj.jus.br/SCON/jurispruden$\mathrm{cia} /$ toc.jsp? repetitivos $=$ REPETITIVOS\&processo $=1657156 \& b=$ ACOR\&thesaurus $=J U R I D I C O \& p=-$ true>. Acesso em: 22 nov. 2018.

BRASIL. Supremo Tribunal Federal. Mandado de Segurança n 34483 MC, Relator: Min. Dias Toffoli, Segunda Turma, julgado em 22/11/2016. Disponível em: < http://stf.jus.br/portal/jurisprudencia/listarJurisprudencia.asp?s1=\%28MANDADO+DE+SEGURANCA+N\%BA+34483+MC\%29\&base=baseAcordaos\&url=http://tinyurl.com/y4nwhrt5> Acesso em: 13 dez. 2018.

BRASIL. Supremo Tribunal Federal. Medida Cautelar em Ação de Descumprimento de Preceito Fundamental (ADPF) no 405-RJ, Relatora: Min. Rosa Weber, Tribunal Pleno, julgado em 14/06/2017. Disponível em: <http://stf.jus.br/portal/jurisprudencia/listarJurisprudencia.asp?s1=\%28MANDADO+DE+SEGURANCA+N\%BA+34483+MC\%29\&base=baseAcordaos\&url=http://tinyurl.com/ y4nwhrt5> Acesso em: 13 dez. 2018.

CALABRESI, Guido; BOBBITT, Philip. Tragic choices. W.W. Norton \& company. Nova lorque, 1984.

CAVALCANTE, Pedro Luiz Costa. Orçamento por Desempenho: Brasil x EUA - análise qualitativa comparada dos modelos de avaliação dos programas governamentais. REGE. Revista de Gestão USP, v. 17, p. 13-25, 2010.

CLÈVE, Clèmerson Merlin; LORENZETTO, Bruno Meneses. Diálogos institucionais: estrutura e legitimidade. Revista de Investigações Constitucionais, v. 2, n. 3, p. 183-206, 2015.

COPETTI, André. Comentário ao artigo 5०, LX. In: CANOTILHO, J. J. Gomes; MENDES, Gilmar F.; SARLET, Ingo W. Comentários à Constituição do Brasil. São Paulo: Saraiva/Almedina, 2013. p. 831-836.

DONIZETTI, Elpídio. Curso Didático de Direito Processual. 19a. ed. São Paulo: Gen, 2016. 
DUBOIS, Philip L. Accountability, independence, and the selection of state judges: The role of popular judicial elections. SW LJ, v. 40, 1986.

GAJARDONI, Fernando da Fonseca. Flexibilidade procedimental: um novo enfoque para o estudo do procedimento em matéria processual. Tese (doutorado em direito processual) - Faculdade de Direito, Universidade de São Paulo, São Paulo, 2008.

GAJARDONI, Fernando da Fonseca; SOUZA, Maurício Bearzotti de. Os princípios da adequação, da adaptabilidade e da flexibilização procedimental pelo juiz no Novo CPC. Revista do Tribunal Superior do Trabalho, v. 82, p. 165-186, 2016.

GEYH, Charles Gardner. Rescuing judicial accountability from the realm of political rhetoric. Case W. Res. L. Rev., v. 56, p. 911, 2005.

GUERRA, Sérgio; DE PALMA, Juliana Bonacorsi. Art. 26 da LINDB-Novo regime jurídico de negociação com a Administração Pública. Revista de Direito Administrativo, p. 135-169, 2018.

HECKMAN, James J. The economics of inequality: The value of early childhood education. American Educator, v. 35, n. 1, 2011.

HOGG, Peter W.; BUSHELL, Allison A. The Charter Dialogue between Courts and Legislatures (Or Perhaps the Charter of Rights Isn't Such a Bad Thing after All). Osgoode Hall Law Journal, v. 35, n. 1, p. 75-124, 1997.

JORDÃO, Eduardo. Art. 22 da LINDB - Acabou o romance: reforço do pragmatismo no direito público brasileiro. Revista de Direito Administrativo, Rio de Janeiro, p. 63-92, nov. 2018.

JUSTEN FILHO, Marçal. Art. 20 da LINDB - Dever de transparência, concretude e proporcionalidade nas decisões públicas. Revista de Direito Administrativo, Rio de Janeiro, p. 13-41, nov. 2018. KOMESAR, Neil K. Taking Institutions Seriously: Introduction to a Strategy for Constitutional Analysis. The University of Chicago Law Review, v. 51, p. 366, 1984.

LEÃO, André Ladeira da Rocha. Da universalização "judicial" do direito à saúde à uniformização de sua tutela. Coleção “CONSTITUIÇÃO DO BRASIL 30 anos 1988 - 2018”. TJMG. Belo Horizonte, p. $57-77,2018$.

LEITE, Ivan Corrêa; DE OLIVEIRA BASTOS, Paulo Roberto Haidamus. Judicialização da saúde: aspectos legais e impactos orçamentários. Argumentum, v. 10, n. 1, p. 102-117, 2018.

LETTERIELLO, Rêmolo. Mato Grosso do Sul: onde nasceram os juizados especiais. Tribunal de Justiça. Poder Judiciário. Mato Grosso do Sul. 2005. Disponível em: <http://tjms.jus.br/juizados/ doutrina/DTR_20050607181401.pdf> Acesso em: 13 mar. 2019.

LEVIN, Ronald M. Administrative Procedure and Judicial Restraint. Harvard Law Review, v. 129, p. 338-349, 2016. 
LIMBERGER, Têmis. Transparência administrativa e novas tecnologias: o dever de publicidade, o direito a ser informado e o princípio democrático. Revista de Direito Administrativo, v. 244, p. 248-263, 2007.

MAINGUÉ NETO, Wilson. Efetivação do Direito à Assistência à Saúde. $1^{\text {a }}$ ed. São Paulo: Max Limonad, 2016.

MARINONI, Luiz Guilherme. Da teoria da relação jurídica processual ao processo civil do estado constitucional. Revista Jurídica. Sapucaia do Sul, RS: Notadez, n. 347, p. 275-306, set./2006.

MASCARENHAS, Caio Gama. Recorribilidade de imediato das decisões interlocutórias nos Juizados Especiais da Fazenda Pública: isonomia e interesse público. Revista dos Juizados Especiais, v. 19, p. 23-37, 2017.

MASCARENHAS, Caio Gama. Inconstitucionalidade da dispensa econômica de remessa necessária do CPC. Revista Eletrônica de Direito Processual, v. 19, n. 3, p. 138-171. 2018.

MATO GROSSO DO SUL. Tribunal de Justiça do Estado do Mato Grosso do Sul. Termo de cooperação técnica n. 01/2017-MPF/PR/MS/GABPRDC. Estipula cláusulas para execução de cirurgias ortopédicas em cumprimento de decisões judiciais. Disponível em: <https://www.tjms.jus.br/_estaticos_/nat/termo_cooperacao_tecnica_mpf.pdf>. Acesso em: 19 maio 2019.

MATO GROSSO DO SUL. Tribunal de Justiça do Estado do Mato Grosso do Sul. Portaria $\mathbf{n}^{\circ} \mathbf{8 8 1}$ de 12 de fevereiro de 2016. Aprova o Regulamento Interno do Núcleo de Apoio Técnico - NAT. Disponível em: <https://www.tjms.jus.br/_estaticos_/nat/Portaria_NAT.pdf>. Acesso em: 19 maio 2019.

ONU. ORGANIZAÇÃO DAS NAÇÕES UNIDAS. A Agenda 2030 para o Desenvolvimento Sustentável. 2015. Disponível em: <https://nacoesunidas.org/wp-content/uploads/2015/10/agenda2030-pt-br.pdf >. Acesso em: 15 out. 2018.

ORME, Bill. De la regulación a la implementación: políticas de acceso a la información en acción. Cuadernos de Discusión de Comunicación e Información, v. 8, p. 5-24, 2017.

PLATT NETO, Orion Augusto et al. Publicidade e transparência das contas públicas: obrigatoriedade e abrangência desses princípios na administração pública brasileira. Contabilidade Vista \& Revista, v. 18, n. 1, p. 75-94, 2009

RIBAS, Lídia Maria; GOUVEIA, Jorge Bacelar. Os conflitos nas sociedades brasileira e portuguesa do Século XXI. THEMIS: Revista da Faculdade de Direito da UNL, p. 7-21, 2015.

RIBAS, Lídia Maria; COSTA, Thaise Graziottin. Inovação na Jurisdição Estatal: de Contenciosa para uma Jurisdição Singular, Compartilhada, Efetiva, Democrática e Emancipatória. Conpedi Law Review, v. 3, n. 1, p. 190-215, 2017. 
RIBEIRO, Luiz Filipe de Araújo. Negócios processuais e seus limites a partir da teoria liberal dos direitos fundamentais. Dissertação (mestrado em direito constitucional) - Universidade Federal do Rio Grande do Norte, Natal, 2017.

ROCASOLANO, Maria Mendez; SILVEIRA, Vladmir Oliveira da. Direitos Humanos: conceitos, significados e funções. São Paulo: Saraiva, 2010.

SARLET, Ingo Wolfgang. Comentário ao artigo 196. In: CANOTILHO, J. J. Gomes; MENDES, Gilmar F.; SARLET, Ingo W. Comentários à Constituição do Brasil. São Paulo: Saraiva/Almedina, 2013. p. 3550-3563.

SCAFF, Fernando Facury. Orçamento republicano e liberdade igual: ensaio sobre Direito Financeiro, República e Direitos Fundamentais no Brasil. Belo Horizonte: Fórum, 2018.

SHAH, Anwar. A Practitioner's Guide to Intergovernmental Fiscal Transfers. In: SHAH, Anwar; BOADWAY, Robin. Theory and Practice of Intergovernmental Transfers: principles and practice. The International Bank for Reconstruction and Development. The World Bank. Washington, DC. 2007.

VERMEULE, Adrian. Deference and Due Process. Harvard Law Review, v. 129, p. 1890, 2015.

VERONESE, Alexandre et al. Vida de assessor: as funções de assessoria judiciária em tribunais superiores no Brasil e nos Estados Unidos em perspectiva comparada. Revista Semestral do Departamento e do Programa de Pós-Graduação em Sociologia da UFSCar, v. 7, n. 2, p. 365, 2017.

ZEBULUM, José Carlos. Juizados Especiais: uma solução para a questão da saúde?. Cadernos Ibero-Americanos de Direito Sanitário, v. 6, n. 1, p. 180-206, 2017. 